Published in final edited form as:

Free Radic Res. 2008 August ; 42(8): 689-706. doi:10.1080/10715760802317663.

\title{
Glutathione and apoptosis
}

\author{
Magdalena L. Circu and Tak Yee Aw \\ Department of Molecular \& Cellular Physiology, Louisiana University Health Sciences Center, \\ Shreveport, Louisiana, USA
}

\begin{abstract}
Apoptosis or programmed cell death represents a physiologically conserved mechanism of cell death that is pivotal in normal development and tissue homeostasis in all organisms. As a key modulator of cell functions, the most abundant non-protein thiol, glutathione (GSH), has important roles in cellular defense against oxidant aggression, redox regulation of proteins thiols and maintaining redox homeostasis that is critical for proper function of cellular processes, including apoptosis. Thus, a shift in the cellular GSH-to-GSSG redox balance in favour of the oxidized species, GSSG, constitutes an important signal that could decide the fate of a cell. The current review will focus on three main areas: (1) general description of cellular apoptotic pathways, (2) cellular compartmentation of GSH and the contribution of mitochondrial GSH and redox proteins to apoptotic signalling and (3) role of redox mechanisms in the initiation and execution phases of apoptosis.
\end{abstract}

\section{Keywords}

Glutathione redox; redox signalling; redox control of apoptosis; mitochondrial GSH and apoptosis; redox and caspase activation

\section{Introduction}

\section{Overview of the apoptotic machinery}

Among the various recognized forms of cell death that include necrosis and autophagy, apoptosis is evolutionarily conserved and highly organized and is characterized by unique nuclear changes, chromatin shrinkage, DNA fragmentation, membrane blebbing and the formation of apoptotic bodies that contain components of the dying cell [1]. The morphological features of apoptosis are generated during the activation of cellular cysteine

(C) 2008 Informa UK Ltd.

Correspondence: Tak Yee Aw, PhD, Department of Molecular \& Cellular Physiology, LSU Health Sciences Center, 1501 Kings Highway, Shreveport, LA 71130, USA. Tel: 318-675-6032. Fax: 318-675-4217. taw@1suhsc.edu.

Accepted by Professor B. Halliwell

Full terms and conditions of use: http://www.informaworld.com/terms-and-conditions-of-access.pdf

This article may be used for research, teaching and private study purposes. Any substantial or systematic reproduction, re-distribution, re-selling, loan or sub-licensing, systematic supply or distribution in any form to anyone is expressly forbidden.

Publisher's Disclaimer: The publisher does not give any warranty express or implied or make any representation that the contents will be complete or accurate or up to date. The accuracy of any instructions, formulae and drug doses should be independently verified with primary sources. The publisher shall not be liable for any loss, actions, claims, proceedings, demand or costs or damages whatsoever or howsoever caused arising directly or indirectly in connection with or arising out of the use of this material.

Declaration of interest: The authors report no conflicts of interest. The authors alone are responsible for the content and writing of the paper. 
proteases (caspases) that can occur through two main apoptotic pathways: death receptor- or mitochondria-mediated pathways.

The extrinsic death receptor mediated pathway is triggered by extrinsic signals, such as extracellular hormones or components of the tumour necrosis factor family (TNF), like TNFa, Fas/CD95 ligand or TRAIL which bind to death receptors on the plasma membrane. At the level of the activated receptor, proapoptotic proteins interact through their death domains or death effector domains, resulting in the formation of the death-inducing signalling complex (DISC). Initiator caspases, such as caspase- 8 or caspase-10 are recruited to the DISC and, upon activation, they trigger a caspase cascade that determines the downstream activation of executioner caspases -3 and -7 , followed by cellular demise by apoptosis [2] (Figure 1). In certain cell types, the activation of caspase-8 was weak and, therefore, insufficient to complete cell apoptosis; in these cells, the cleavage of the proapoptotic protein Bid by activated caspase- 8 , engaged the mitochondrial apoptotic cascade [3], indicating a degree of cross-talk between the death receptor and mitochondrial pathways in apoptotic signalling (Figure 1).

The intrinsic mitochondrial apoptotic pathway involves the mitochondria-to-cytosol release of pro-apoptotic proteins. Different apoptotic stimuli, such as reactive oxygen and nitrogen species (ROS/RNS) and mitochondrial DNA damage, can mediate mitochondrial outer membrane permeabilization and the release of mitochondrial pro-apoptotic factors, like cytochrome $c$ (cyt $c$ ), apoptosis inducing factor (AIF) or second mitochondria-derived activator of caspases/direct IAP binding protein with low $\mathrm{pI}$ (Smac/Diablo). Within the cytosol, these apoptogenic factors trigger caspase-dependent or caspase-independent signalling events. For example, cyt $c$ binds to the apoptotic protease-activating factor-1 (Apaf-1) and forms the apoptosome to which procaspase-9 is recruited. The ATP-dependent cleavage of procaspase- 9 signals downstream cleavage/activation of effector caspases, -3 and -6/7 (Figure 1). Additionally, Smac/Diablo, which antagonizes inhibitors of caspases, enhances caspase activation. Interestingly, through mitochondria-to-nuclear translocation, AIF participates in caspase-independent mitochondria-mediated apoptosis where it induces chromatin condensation and DNA fragmentation [4].

Mechanisms of pro-apoptotic protein release-How mitochondrial pro-apoptotic proteins are released into the cytosol is not fully understood. One mechanism involves the formation of a megapore at the level of the inner and outer mitochondrial membrane, the permeability transition pore (PTP), that would allow entry of small solute molecules and water into the matrix. Increased osmosis would induce mitochondrial swelling, rupture of the outer mitochondrial membrane and release of pro-apoptogenic proteins into the cytosol $[5,6]$. The molecular composition of PTP is hotly debated, but recent findings point to the fact that only cyclophylin D (cypD) is a permanent constituent and modulator of PTP. The two other components, voltage-dependent anion channel (VDAC) and the adenine nucleotide translocase, participate only in a limited extent in the formation of PTP [7-9]. Interestingly, glyceraldehyde-3-phospate dehydrogenase (GAPDH), a glycolytic enzyme, has been suggested to play a role in cell death associated with the opening of the PTP complex. In this regard, exogenously added GAPDH can be imported and interact with VDAC 1 resulting in cyt $c$ and AIF release [10]. However, this involvement of mitochondrial permeability transition (MPT) was mostly associated with cell necrosis and/or localized mitochondrial $\mathrm{Ca}^{2+}$ overload [11,12].

A second mechanism underscores a role for proapoptotic members of the Bcl-2 family of proteins in permeabilization of the mitochondrial outer membrane. Key members of over 30 proteins that belong to the Bcl-2 superfamily, namely anti-apoptotic proteins, pro-apoptotic proteins and $\mathrm{BH} 3$-only proteins, participate in the control of release of mitochondrial 
apoptogenic factors. Normally, the anti-apoptotic proteins, like Bcl-2, Bcl-XL and Diva, interact with pro-apoptotic Bcl-2 proteins such as Bax/Bak or with the BH3-only proteins to prevent apoptogenic factor release. However, activation of cytosolic BH3-only proteins promote Bax/Bak protein conformational change and protein oligomerization which induce large pore formation in the outer mitochondrial membrane [13]. Interaction of Bax/Bak with components of the PTP (e.g. VDAC) further contributes to outer mitochondrial membrane permeabilization [14]. Thus, the apoptotic susceptibility of a cell is a function of the balance in actions of anti- and pro-apoptotic proteins. Additionally, a reorganization of the mitochondrial cristae can influence cyt $c$ release. In particular, optic atrophya 1 protein (OPA1), an inner membrane protein which controls cristae junction (CJ) integrity, is involved in this process. Studies in isolated mitochondria and cell cultures have shown that $\mathrm{Ca}^{2+}$ induced endoplasmic reticulum (ER) stress promoted MTP-induced mitochondrial remodelling and the release of OPA1 protein, that led to cyt $c$ release and apoptosis [15]. In other studies, Frezza et al. [16] demonstrated the involvement of soluble OPA1 and inner mitochondrial membrane-bound OPA, in the formation of oligomers that tightened the CJ and prevented cyt $c$ release and apoptosis. In contrast, disruption of OPA1 oligomers by Bid (activated BH3-only protein) widened the CJ and promoted cyt $c$ release [16].

\section{GSH: Synthesis and cellular compartmentation}

The tripeptide, glutathione (L- $\gamma$-glutamyl-L-cysteinyl-glycine, GSH) is the most abundant intracellular thiol, reaching millimolar concentrations in most cell types. GSH is involved in many cellular functions including antioxidant defense via direct interaction with ROS or via activities of detoxication enzymes like GSH peroxidases and GSH-S-transferases [17]. Importantly, GSH plays an essential role in maintaining the intracellular redox environment that is critical for function of various cellular proteins. Cellular GSH is predominantly present in the reduced thiol form, GSH, which is also the biologically active form. Under oxidizing conditions, oxidation of GSH to its disulphide, GSSG, results in a decreased GSHto-GSSG ratio.

In mammalian cells, three mechanisms serve to maintain GSH homeostasis, namely de novo synthesis, uptake from exogenous sources across plasma membranes and GSSG reductasecatalysed reduction of GSSG. De novo GSH synthesis occurs exclusively in the cytosolic compartment, in two sequential ATP-dependent steps that are catalysed by glutamate cysteine ligase (GCL) and GSH synthetase [18] (Figure 2). GCL-catalysed formation of $\gamma$ glutamyl-cysteine is the first and rate-limiting reaction in GSH synthesis and is feedbackinhibited by GSH itself, a mechanism that is central in the regulation of cellular GSH concentrations [19]. Cysteine is a rate-limiting substrate for de novo GSH synthesis and is derived from extracellular GSH breakdown by $\gamma$-glutamyl transferase (GGT) and/or from methionine-to-cysteine conversion through the cystathionine pathway [20]. While the cystathionine pathway is characteristic for liver cells, the cleavage of circulating GSH takes place at external plasma membrane surfaces of various epithelial cells such as kidney, pancreas, bile duct and small intestine. In the GGT-catalysed reaction, the $\gamma$-glutamyl moiety is transferred from GSH or GSH conjugates to acceptors like amino acids, dipeptides or GSH itself, while cysteinylglycine is cleaved by membrane-bound dipeptidases. The resultant constituent amino acids and $\gamma$-glutamyl products are taken up into cells for de novo GSH synthesis (Figure 2). Thus, the GGT reaction is part of the $\gamma$-glutamyl cycle in intracellular GSH synthesis and GSH homeostasis [21,22]. Interestingly, cysteine has been shown to be an acceptor of the $\gamma$-glutamyl moiety; the product $\gamma$-glutamylcysteine was transported through specialized carriers into cells and used directly in GSH synthesis, thereby bypassing the feedback inhibition of GCL [23,24]. This mechanism appears to be important in cellular GSH control in kidney cells under physiological and stress conditions [24]. For example, the administration of $\gamma$-glutamyl-cysteine in mice significantly increased 
kidney GSH levels, suggesting that the administered dipeptide was efficiently transported for de novo GSH synthesis [24]. This mechanism of GSH synthesis further functions as a physiological pathway of cysteine recovery. In addition, extracellular GSH can be taken up intact into renal cells across basolateral plasma membrane via $\mathrm{Na}^{+}$-dependent or independent processes [25-27]. This mechanism of GSH uptake was responsible for half of the total $80 \%$ of GSH extraction by kidney from plasma $[28,29]$ and for protection of proximal tubular cells against $t \mathrm{BH}$ toxicity and ATP depletion [25,30]. GGT-catalysed GSH degradation constituted the remaining $30 \%$ of total renal GSH uptake and regulation of cellular GSH levels. An efficient system for cellular GSH regeneration is the catalytic reduction of GSSG by NADPH-dependent GSSG reductase, commonly known as the GSH redox cycle (Figure 2). GSSG reductase is distributed in both the cytoplasmic and mitochondrial compartments.

GSH compartmentation-Much research in recent years on redox signalling and redox regulation of cell function is spurred by the recognition of the existence of well defined compartments of redox systems within cells, each exhibiting a unique redox environment. Intracellular GSH is compartmentalized within the mitochondria, nucleus and endoplasmic reticulum (ER), all of which constitute separate redox pools that are distinct from the cytoplasmic pool in terms of distribution of the GSH and GSSG forms, their redox potential and their control of cellular activities. Cytoplasmic GSH concentration is in the range of 2$10 \mathrm{mM}$; in the liver [21], a highly reduced GSH-to-GSSG ratio is normally maintained in excess of 100-to-1 and this ratio can significantly decrease to less than 4-to-1 during oxidative stress. Highly reduced baseline cytoplasmic GSH redox pools are similarly maintained in other cell types.

The ER pool typically exhibits GSH concentrations similar to the cytosolic compartment (2$10 \mathrm{mM}$ ). A unique feature of the ER redox environment is that it is distinctively oxidized, a state that favours disulphide bond formation and proper folding of nascent proteins [31], a process that is catalysed by protein disulphide isomerase (PDI), where oxidation of catalytic site thiols is essential to enzyme activity [32]. Precise quantification of the GSH redox status in ER is difficult. Recently, using more precise measures to avoid ex vivo oxidation during sample preparation, GSH concentrations in rat liver microsomes were found to be $\sim 4.5 \mathrm{mM}$ [33], in agreement with previous findings. Reported GSH-to-GSSG values ranged from 1.5:1 to 3:1 in hybridoma cell line [34] and $\sim 3: 1$ to 5:1 in rat liver microsomes [31]. Interestingly, a somewhat more reduced GSH-to-GSSG ratio appears to be favourable in increasing the reductase activity of PDI than a highly oxidized GSH redox ratio [33]. A second notable feature is that less than $50 \%$ of the ER thiol pool (GSH + GSSG) is free; the majority of GSH is reversibly bound to proteins as protein mixed disulphides [31]. Functionally, GSH serves to maintain oxidoreductase catalytic function and as a redox buffer against ER-generated ROS [35,36]. Changes in the GSH redox state can disrupt ER function, activate the unfolding protein response (UPR) and trigger cell apoptosis [37].

The nucleus exhibits an independent GSH pool that plays an important role in protection against oxidant- and ionizing radiation-induced DNA damage [38] and in preserving nuclear proteins in a reducing environment for gene transcription during cell cycle progression [39]. In addition, GSH functions as a hydrogen donor in ribonucleotide reductase-catalysed reduction of ribonucleotides to deoxyribonucleotides and thus plays a contributory role in DNA synthesis [40,41]. While the quantitative pool size of nuclear GSH is difficult to assess, recent evidence suggests that the nuclear GSH pool is not in equilibrium with cytosolic GSH. Higher nuclear-to-cytosolic GSH levels have been reported in rat hepatocytes (3:1) [42], human tumour biopsy samples [43] and A549 cells [44]. Importantly, nuclear GSH distribution is a dynamic process and correlates directly with cell cycle progression; a 4-fold higher nuclear-to cytosolic GSH was associated with the proliferative 
state while equal distribution between the two compartments occured in confluent cells $[39,45]$. The mechanisms that govern the dynamics of nuclear GSH distribution are unresolved. One suggested mechanism is a passive diffusion of GSH from the cytosol to the nucleus via nuclear pores [46], but precisely how a passive transport system could achieve the distinctiveness of a nuclear GSH pool is unclear. Although incompletely understood, a role for the anti-apoptotic protein $\mathrm{Bcl}-2$ has been implicated in maintaining a high nuclear GSH concentration [47].

A distinct mitochondrial GSH pool is metabolically separated from the cytosolic pool in terms of GSH synthesis rate, GSH turnover and its sensitivity to oxidative stress [44]. Mitochondrial matrix GSH concentrations are between 5-10 mM and are cell-type specific, varying from $10-15 \%$ of the total GSH in the liver [48] to $15-30 \%$ of total GSH pool in the renal proximal tubule [49]. In contrast to the cytosol, mitochondria are incapable of de novo GSH synthesis, being deficient in GCL and GSH synthase. As such, matrix GSH homeostasis is highly dependent upon GSH import from the cytosolic compartment via the dicarboxylate and 2-oxoglutarate GSH transport carriers located in the mitochondrial inner membrane [50]. Little is known of the control of these anion transporters, but recent evidence in cultured neuronal cells implicated a role for Bcl-2, the anti-apoptotic protein, in the modulation of localized mtGSH pool at mitochondrial membrane sites [51]. Bcl-2 was shown to directly bind GSH via the $\mathrm{BH} 3$ groove; the disruption of this interaction by proapoptotic proteins such as BimL caused GSH displacement from the mitochondria as well as inhibition of mitochondrial GSH transport [51].

\section{GSH redox state and cell apoptosis}

\section{Cellular GSH in cell transition and apoptotic cell death}

A decrease in cellular GSH concentration has long been reported to be an early event in the apoptotic cascade induced by death receptor activation [52], mitochondrial apoptotic signalling [53], drug exposure [54,55] and oxidative stress [56,57]. Decreases in cellular GSH levels have been attributed to two fundamental mechanisms, namely direct GSH oxidation promoted by ROS or GSH export from cells. Not surprisingly, elevated GSH levels afforded protection against stress-induced apoptosis [58,59]; specifically, apoptosis prevention was associated with GSH protection of redox active cysteines at the catalytic sites of caspases $[58,60]$. However, protection against caspase activation by decreased GSH has been reported in hepatocytes $[61,62]$. To date, the precise role of GSH in the complex and multi-step process of cell apoptosis remains unclear and clarity is likely to be further complicated by cell type specificity and nature of pro-apoptotic stimuli. This notwithstanding, studies from our laboratory have provided evidence for a role for the GSH/ GSSG redox status in cell apoptosis in various cell types [63,64]. We found that oxidantinduced cell apoptosis was consistently associated with oxidant-induced GSH/GSSG imbalance, specifically a rise in GSSG, which kinetically preceded loss of mitochondrial integrity, mitochondria-to-cytosol cyt $c$ translocation and caspase-3 activation. Importantly, the significant increase in GSSG occurred within a narrow window of redox shift, generally the first 30 min post-oxidative challenge and subsequent recovery of cellular GSH/ GSSG balance by $1 \mathrm{~h}$ did not influence the apoptotic endpoint, a response that is consistent with an early initiation of redox signalling. This suggestion was further supported by our finding that oxidant-induced cell apoptosis was blocked by pre-treatment with the thiol antioxidant, Nacetylcysteine (NAC), which effectively prevented GSSG increase; notably, NAC was without effect when administered at a time after the rise in GSSG has occurred [63, 65,66]. Collectively, our results suggest that GSH redox-dependent apoptosis initiation is an early event in the apoptotic cascade that is likely to be a generalized paradigm in many cell types. Interestingly, apoptosis in certain mitotic competent undifferentiated cells, such as PC12, can be induced by a loss of cellular redox balance independently of ROS production [65], 
suggesting a mechanistic dissociation between a redox vs a direct ROS effect. Decreases in NADPH availability for GSSG reduction contributed to sustained cellular redox imbalance that potentiated cell apoptosis [65].

Additional studies reveal a broader role for cellular GSH/GSSG redox balance in cell transition to proliferative, differentiated or apoptotic phenotype over a wide continuum of GSH redox changes [67-69]. We found that lipid hydroperoxide elicited differential intestinal $(\mathrm{CaCo}-2)$ cell transition into the proliferative or apoptotic states, depending on the degree of GSH redox shift. At 10-20 $\mu_{\mathrm{M}}$, LOOH induced significant cellular GSH/GSSG redox disruption, mitochondrial dysfunction, caspase-3 activation and DNA fragmentation consistent with cell apoptosis [68]. A low level of redox imbalance elicited by $1-5 \mu_{\mathrm{M}}$ $\mathrm{LOOH}$ favoured cell proliferative responses as evidenced by increases in DNA synthesis and ornithine decarboxylase activity and expression of cyclin D1 and cdk4 [68], consistent with $\mathrm{G}_{1}$ exit and $\mathrm{S}$ phase progression. Enhanced $\mathrm{CaCo}-2$ cell proliferation was inhibited by extending the duration of the mild redox imbalance and resulted in cell growth arrest at the $\mathrm{G}_{2} \mathrm{M}$ phase, which was reversible [67]. These collective results underscore a role for cellular GSH redox state in intestinal cell proliferation, growth arrest or apoptosis that directly tracked with the extent of GSH/GSSG redox alteration. A similar response to early GSH/ GSSG redox imbalance caused by tert-butylhydroperoxide $(t \mathrm{BH})$ was observed in apoptosis of mitotic competent undifferentiated PC12 cells [64,65]. Interestingly, by inducing PC12 differentiation, we obtained a phenotype that was significantly more resistant to $t \mathrm{BH}$ and this resistance to oxidative damage corresponded to a highly reduced intracellular GSH redox environment and decreased expression of Apaf-1 [65], suggesting that the GSH redox status can influence differential apoptotic susceptibility in various cell phenotypes.

Subsequently, we established that the decreased susceptibility of a differentiated phenotype like PC12 cells extended to other oxidative challenges as well, such as carbonyl stress [70] and hyperglycemic stress [71,72].

\section{Mitochondrial GSH and apoptosis}

Mitochondrial GSH (mtGSH) depletion is associated with varied human pathologies such as diabetic retinopathy [73], cardiovascular disease [74], hepatocellular complications [75] and kidney stone disease [76], consistent with a role for mtGSH in human health and disease. Of relevance to the current review is the consideration of mtGSH redox status in mitochondrial apoptotic signalling. Functionally, mtGSH participates in preserving the integrity of mitochondrial proteins and lipids and in controlling mitochondrial ROS generation. Mechanistically, oxidative susceptibility is associated with an increase in mitochondrial ROS production secondary to matrix GSH decrease, mitochondrial membrane potential loss, mitochondria-to-cytosol cyt $c$ release and initiation of the apoptotic cascade [77]. The precise contribution of mtGSH redox status to the apoptotic process remains to be defined despite a clear link between cellular GSH and cell apoptosis [78]. Early evidence suggests a mechanistic role for oxidation of thiols [79] in modulating MPT in that thiol oxidation determines pore function, consistent with apoptosis initiation. Functional divalent thiolreactive agents were shown to promote apoptosis by inducing formation of disulphide-cross links which blocked anti-apoptotic Bcl-2 function in preventing MPT [80]. A direct role for mitochondrial redox (i.e. increased GSSG relative to GSH) has not been explored. Distinguishing between regulation by GSH or by GSH-to-GSSG ratio is a relevant mechanistic issue given the findings that changes in their respective status yielded different cellular outcomes in different cell lines [63,65,67,81,82].

The importance of mtGSH in cell survival is underscored by literature evidence of its role in oxidative vulnerability [83] and oxidant-induced apoptosis [66]. As examples, alterations of mtGSH have been linked to cytotoxicity induced by aromatic hydrocarbons [84], hypoxia [85], tert-butylhydroperoxide ( $t \mathrm{BH}$ ) [86] and ethanol intoxication [87]. In models of ethanol- 
induced hepatocellular injury [87-89], ethanol has been shown to deplete mtGSH by blocking cytosol-to-mitochondrial uptake of GSH due to mitochondrial enrichment with cholesterol and altered membrane fluidity [87]. Moreover, ethanol-mediated mtGSH decreases potentiated hepatocyte apoptosis to acetaminophen [90] and TNF $\alpha$ [91]. The mechanism of TNF $\alpha$-mediated hepatocyte apoptosis was correlated with caspase-8 activation and mitochondria-derived ROS production [92]. Notably, apoptotic death dominated, despite the lack of an effect of mtGSH depletion on TNF $\alpha$-induced NF- $\mathrm{KB}$ activation of survival signals. In hepatocyte models of hypoxic injury, potentiation of mitochondria-derived ROS signalled cell apoptosis upon depletion of mtGSH [85]. Interestingly, Lluis et al. [77] found that mitochondrial ROS production consequent to mtGSH depletion exhibited dual roles in carcinoma cell lines. Early formation of ROS promoted cell survival through NF- $\kappa \mathrm{B}$ activation via c-Src-mediated phosphorylation of I $\kappa \alpha \alpha$ and stabilization of HIF $1 \alpha$, while excessive ROS production stimulated cyt $c$ and $\mathrm{S}_{\mathrm{MAC}}$ Diablo release, mitochondrial membrane potential loss and apoptotic signalling [77]. In an acute streptozotocin-induced diabetic rat model, a similar relationship existed between reduction in mtGSH and increased mitochondrial ROS production in apoptosis of cardiomyocytes that was associated with changes in mitochondrial membrane potential and activation of caspase-9 and -3 [74]. A similar mechanism of ROS-induced mtGSH loss and apoptosis was demonstrated in chronic rodent models of diabetes, underscoring the importance of mtGSH loss in diabetes-mediated cardiac apoptotic death [93].

In models of chemical toxicity, nephrotoxicity and renal cell apoptosis induced by cisplatin was linked to mitochondrial dysfunction and decreases in mtGSH and NADPH levels as well as loss of mitochondrial membrane potential, oxidation of cardiolipin and caspase-3 activation [94]. Consistent with a role for ROS, the administration of dimethylthiourea (DMTU), a non-specific scavenger of hydroxyl radicals, prevented the effects of cisplatin on renal mitochondrial redox state, bioenergetics and oxidative stress $[95,96]$. In other studies, silica-induced apoptosis in rat alveolar macrophages was accompanied by a decrease in mtGSH which resulted in increased mitochondrial ROS production, cyt $c$ release and caspase-9 activation [97]. The exposure of undifferentiated PC-12 cells to 4-hydroxynonenal was associated with time- and dose-dependent decreases in mitochondrial and extramitochondrial GSH, inhibition of GSH- reductase and peroxidase activities and oxidative stress that induced cyt $c$ release, PARP [poly-(ADP-ribose) polymerase] activation, DNA fragmentation and apoptosis [98].

Despite the recognition of the importance of mtGSH in cell survival, an early challenge to efforts in delineating the mechanistic contribution of this redox compartment to the initiation of cell apoptosis has been the difficulty in quantifying and manipulating the mitochondrial GSH pool. A significant advancement in methodology to alter cytosol-to-matrix GSH uptake was the chemical and genetic modulation of the energy-dependent carrier-mediated transport systems located in the inner membrane of the mitochondria $[50,99,100]$. In liver and kidney, the dicarboxylate (DIC) and 2-oxoglutarate (OGC) membrane carriers are two known mitochondrial GSH transporting proteins [50,101]. Previous studies demonstrated that over-expression of DCC in a rat kidney proximal tubule cell line increased the mtGSH pool size by 2-10-fold over wild-type cells [102] and the functional expression of the hepatic OGC carrier in X. laevis mitochondria enhanced transport of mtGSH [103]. Lash and colleagues $[102,104]$ found that over-expressing either DIC or OGC in the rat renal proximal tubular NRK-52E cell line significantly attenuated cell apoptosis following exposure to $t \mathrm{BH}$ or S-(1,2-dichlorevinyl)-L-cysteine (DCVC) in association with higher mtGSH levels. In contrast, protection against $t \mathrm{BH}$ - or DCVC-induced apoptosis was abrogated by the over-expression of a double-cysteine mutant of OGC, a non-functional carrier [104]. Using the strategy of targeting mtGSH uptake, we recently provided compelling evidence that mtGSH transport was critical in the maintenance of mitochondrial 
respiratory activity and intestinal cell apoptosis induced by menadione (MQ) [66]. Our results implicate the mitochondria as the site of MQ redox signalling and the semi-quinone radical as the toxic species [66].

Interestingly, in contrast to mtGSH-linked cytoprotection, a recent study reported that mitochondrial GSH/GSSG redox imbalance in favour of the reduced species GSH was associated with reductive stress and cell apoptosis. Chronic exposure of mice to 2,3,7,8tetrachloredibenzo-p-dioxin (TCDD) increased mtGSH relative to GSSG, as compared to significant decreases in cytosolic GSH and increases in GSSG and oxidized protein [105]. Promotion of a reductive state in the matrix and elevation of mtGSH stimulated succinatedependent mitochondrial production of $\mathrm{H}_{2} \mathrm{O}_{2}$ that resulted in oxidative damage to mitochondrial DNA. It was suggested that mitochondrial reductive stress can induce the inhibition of the flickering mode of the MPT that resulted in a more negative membrane potential [105].

\section{Mitochondrial GSH redox, oxidative DNA damage and apoptosis}

Cellular DNA damage upon exposure to a wide range of environmental genotoxins, anticancer drugs or ROS can induce a cascade of events that result in either cell cycle arrest and DNA repair or in cell apoptosis if the damage is extensive [106]. As compared to the nuclear genome, the mitochondrial genome is highly vulnerable to oxidative stress [107] given its open circular structure and lack of histone protection and its proximity to the mitochondrial electron transport chain, a main source of superoxide radical $\left(\mathrm{O}_{2}^{-}\right)$and $\mathrm{H}_{2} \mathrm{O}_{2}$. Oxidative mtDNA modifications comprise of damage to purine and pyrimidine bases, sugarphosphates as well as single- or double-strand breaks in DNA [108], of which the formation of 7,8-dihydro-8-oxoguanine (8oxodG) [109,110] is common during oxidative stress [111]. Oxidative base damage does not involve direct $\mathrm{O}_{2}{ }^{-}$or $\mathrm{H}_{2} \mathrm{O}_{2}$ attack on DNA; rather, base modifications are characteristic of attack by hydroxyl radical $(\mathrm{OH})$ generated through reactions of $\mathrm{H}_{2} \mathrm{O}_{2}$ with metal ions (iron or copper) in close proximity to DNA [110]. However, $\mathrm{O}_{2}{ }^{-}$or $\mathrm{H}_{2} \mathrm{O}_{2}$ (such as derived from quinone redox cycling) can induce DNA strand breaks reflective of endonuclease activation [110]. While lacking important nuclear nucleotide excision repair, the mitochondrion possesses an efficient base excision repair system for the repair of oxidized bases $[112,113]$. Repair is initiated by mitochondrial DNA glycosylase that recognizes and removes the damaged base, followed by the apurinic (AP) endonuclease that generates an apurinic/apyrimidinic(AP) site. By targeting 8-oxodG glycosylase (OGG1) to the mitochondria, Dobson et al. [114] first demonstrated that enhanced mtDNA repair induced by menadione was associated with cell survival. An adaptive response to increasing ROS concentrations was associated with elevated AP endonuclease 1 levels, increased DNA repair rate and attenuated oxidative mtDNA damage [115].

The increased interest in mitochondrial DNA (mtDNA) damage in the past 10 years comes from the discovery that defects in the mitochondrial genome are associated with several human hereditary diseases and pathologies [116], that many chemotherapeutic agents work through initiation of mtDNA damage [117] and that mtDNA damage induces cell apoptosis [118]. The mitochondrial genome encodes several hydrophobic components of the respiratory chain and mtDNA damage will decrease gene expression of key respiratory proteins [119]. The consequent disruption in electron flow enhances ROS generation and creates a vicious cycle of mitochondrial dysfunction that culminates in cell apoptosis [120]. An emerging focus that we champion in recent years is the role of the mtGSH status in the integrity of the mitochondrial genome and cell survival during oxidative challenge. By directly reacting with ROS or by participating as a cofactor in antioxidant reactions, $\mathrm{mtGSH}$ can have a major impact on the level of oxidative DNA damage under oxidative stress. Previous studies have described a positive correlation between a decrease in the mtGSH 
pool and an increase in mtDNA damage [121]. A correlation between early mtGSH oxidation, quantitatively greater mtDNA damage and cell apoptosis was also observed in vivo in rat lactating mammary gland [122]. In liver mitochondria, sensitization of a specific mtDNA region to deletion by hemin-induced mtGSH loss occurred in association with increases in proapoptotic $\mathrm{Bax}$ and $\mathrm{Bcl}-\mathrm{xL}$ and initiation of mitochondrial apoptotic cascade, suggesting a relationship between mtGSH redox homeostatic status, mtDNA protection and apoptotic signalling [123]. Our studies in intestinal cells have demonstrated that oxidative stress induced by menadione (MQ) elicited a dose-dependent increase in mtDNA damage that was attenuated by NAC pre-treatment, indicating that mtDNA susceptibility to oxidative challenge is redox-sensitive. In this regard, the blockage of GSH synthesis exacerbated MQ-mediated mtDNA damage in accordance with decreases in cellular GSH concentrations, consistent with a responsiveness of the level of mtDNA damage to the cellular GSH state. Importantly, inhibition of mtGSH transport potentiated MQ-induced mtDNA damage while over-expression of mitochondrial OGC conferred protection of mtDNA against MQ which validated a close association between mtGSH and oxidative damage to mtDNA [124]. Collectively, these results support our central hypothesis that the mtGSH redox is a major contributor to mitochondrial genomic integrity and, together, likely control apoptotic initiation and cell susceptibility during oxidative challenge.

\section{Redox proteins and apoptosis}

Complementing the GSH redox system in cell apoptosis is the thioredoxin family of proteins which exhibit important roles in redox signalling, redox regulation of critical cysteine residues in cellular proteins and cell apoptosis. Thioredoxins (Trx) are small ubiquitous proteins that contain two redox active cysteine residues in the catalytic site (Cys-XX-Cys) [125]. Mechanistically, Trx catalyses the reversible reduction of disulphide bonds in oxidized proteins at the expense of cysteine residues in its active motif site; the active reduced Trx is regenerated by Trx reductase and NADPH. The two mammalian forms of Trx, Trx 1 and Trx2, are located in the cytosolic and mitochondrial compartments, respectively. Cytosolic Trx1 is ubiquitously expressed and can translocate to the nucleus during oxidative stress. The cytosolic and nuclear Trx 1 pools are independently controlled and perform different functions [126,127]. Mitochondrial Trx2 possesses a conserved Trxactive site, Trp-Cys-Gly-Pro-Cys, and is involved in antioxidant protection and preservation of mitochondrial redox homeostasis. Compared to cytosolic Trx 1, mitochondrial Trx 2 is relatively more oxidized and is regulated independently of cytosolic Trx 1 and the mitochondrial GSH/GSSG redox couple [126,128].

The Trx redox system, consisting of reduced and oxidized Trx (Trx-SH/Trx-SS), is one of the 'redox control nodes' that acts as a rheostat on/off switch in redox regulation of cellular proteins [129], a concept that is popularized by Jones and coworkers [127,129]. These investigators propose that within cells, three redox systems (cysteine/cystine; GSH/ GSSG and Trx-SH/Trx-SS) function as distinct redox circuitry that are independently controlled and compartmentalized in the plasma membrane, cytosol, nucleus, mitochondria and endoplasmic reticulum [127]. By controlling the redox status of specific protein sets, these specialized redox circuitry independently control the redox environment in each cellular compartment and could represent a generalized and crucial mechanism for redox signalling and optimization of cell activity within mammalian cells.

An example of a Trx-sensitive (but not GSH-sensitive) target protein is the apoptosis signalregulated kinase 1 (ASK1) [128]. Figure 3 summarizes the mechanism of ROS/redox modulation of ASK1 activity and its activation of JNK. ASK1 is a MAPK kinase kinase that is activated by stress signals such as ROS [130], TNF $\alpha$ [131], ER stress and calcium influx [132]. In resting cells, Trx 1 binds to ASK1 through the cysteine residue in the catalytic site and prevents the downstream propagation of the apoptotic signal [130]. Since only the 
reduced form of Trx1 promotes ASK1 degradation, the Trx1/ASK1 couple serves as an intracellular redox switch, named 'ASK1 signalosome', that can be turned on or off under oxidative conditions [133]. The oxidation of Trx 1 by ROS determines its dissociation from ASK1 which promotes the recruitment of TNF receptor-associated factors 2 and 6 (TRAF2/6) and the formation of the activated ASK1 signalosome complex that results in JNK-induced apoptosis $[130,134]$. Additionally, under oxidizing conditions, oxidized Trxinteracting protein (Txnip) also called vitamin D3 upregulated protein 1 (VDUP1) or Trx binding protein-2 (TPB-2), binds to the catalytic cysteine moieties of reduced Trx1 and forms mixed disulphide bonds that result in loss of Trx 1 function. A similar mechanism of ROS-dependent activation of ASK1 has been described in the mitochondria. For example, in human umbilical vein endothelial cells, Trx 2 functions as a redox sensor and inhibitor of the mitochondrial ASK1-mediated apoptotic signaling pathway [135]. In this instance, mitochondrial ASK1 activates both JNK-dependent as well as JNK-inde-pendent apoptotic pathways [135]. ASK2, a serine/ threonine kinase closely related to ASK1, is a partner of ASK1 in the cytosol, nucleus and mitochondria [136]. In non-stressed cells ASK2 forms heteromeric complexes with ASK1 that positively regulate stress-induced kinase activation and negatively regulate caspase-3 activation and PARP cleavage [137]. A disturbance in the balance between ASK-1 and -2, such as occurs during serum starvation, results in activation of JNK-mediated apoptosis.

\section{Role of redox in phases of apoptosis}

\section{Cytochrome c-cardiolipin interaction and initiation of apoptosis}

Cytochrome $c$ (cyt $c$ ) release from the mitochondria is a critical, early event in the mechanism of apoptosis. Within the cytosol, cyt $c$ forms the apoptosome with Apaf-1 and pro-caspase-9 that results in caspase-3 activation [64]. Despite its centrality in apoptosis initiation, the mechanism(s) of cyt $c$ release remains elusive. Much focus has been on cyt $c$ release via mitochondrial permeabilization and PTP and its regulation by members of the Bcl-2 family $[64,138]$. Until recently, the underlying mechanism for cyt $c$ mobilization from its binding to the inner mitochondrial membrane which is pre-requisite for its release has received little attention. A key recognition is the fact that cyt $c$ is a water-soluble basic heme protein anchored to the mitochondrial inner membrane by association with cardiolipin (CL), an anionic phospholipid that locates exclusively in the inner mitochondrial membrane $[139,140]$. CL maintains membrane fluidity, stability and contact between the inner and outer mitochondrial membranes [141] and functions as a facilitator of electron transport between complexes III and IV [142]. The CL-cyt $c$ association is specific and stoichiometric [143] and involves electrostatic interactions at the A-site of cyt $c$ and hydrophobic interactions and hydrogen bonding at its C-site [143]. It has been suggested that it is the breach of these interactions that provides the mechanism for cyt $c$ to leave the mitochondria $[144,145]$.

The release of cyt $c$ from the mitochondria during mitochondrial apoptosis initiation has been proposed to occur by a two-step mechanism, namely the detachment of cyt $c$ from its binding to CL induced by mitochondria-derived ROS, followed by the permeabilization of the mitochondrial outer membrane and the release of cyt $c$ into the cytosol [144]. Current data suggests that selective peroxidation of CL is a requisite first step and subsequent pore formation induced by pro-apoptotic $\mathrm{Bcl}-2$ proteins is responsible for permeabilization of the outer mitochondrial membrane [146,147] (Figure 4). The oxygenase function of cyt $c$ is important in CL peroxidation [146] and it is suggested that low levels of mitochondriaderived $\mathrm{H}_{2} \mathrm{O}_{2}$ facilitate the unfolding of cyt $c$ and the increase in its peroxidatic activity which, interestingly, depends on the unsaturation of the fatty acyl chains of CL. It has been shown that, while saturated fatty acids were resistant to peroxidation, poly-unsaturated fatty acyl chains in CL were highly susceptible to ROS [148,149] and their oxidation was 
associated with the dissociation of cyt $c$ [150]. In contrast to $\mathrm{H}_{2} \mathrm{O}_{2}$, mitochondrial nitric oxide (NO*) at low concentration was a strong inhibitor of cyt $c$ peroxidase activity and CL oxidation [151]. Thus, oxidative modification of CL is pivotal in mitochondrial cyt $c$ loss and cell commitment to apoptosis. Prevention of apoptosis by over-expression of GSH peroxidase $4(\mathrm{Gpx} 4)$ is consistent with CL preservation [152]. In this regard, CL-bound cyt $c$ could be viewed as a mitochondrial oxidative stress sensor and redox regulator of apoptosis [146].

Recent studies suggest that there exists a 'hierarchy of structural transitions' induced by different types of phospholipids in the structure of cyt $c$ that influences its peroxidase activity. For instance, in studies of liposome mixtures of different phospholipids, anionic phospholipids, CL and phosphatidic acid were found to be excellent inducers of cyt $c$ peroxidase activity [153]. Studies in cyt $c$-deficient HeLa cells further revealed that CL and phosphatidyl serine (PS) were the preferred phospholipid substrates [153]. Due to the distinct localization of CL and PS at the mitochondrial and plasma membranes, respectively, it was suggested that specific peroxidation of these phospholipids represented elements of the different stages of apoptosis within cells, namely CL and PS oxidation reflecting the early and late stages of apoptosis [153]. At the level of the mitochondrion, CL relocated to the outer leaflet of the mitochondrial inner membrane post-oxidation, where it reportedly functions as a docking platform for tBid, a proapoptotic protein to induce perforation of the mitochondrial membrane $[154,155]$. A requirement for activated Bax and physiological levels of CL in permeabilization of outer mitochondrial membrane vesicles to dextran was demonstrated in liposomes in vitro [156]. However, direct participation of CL in membrane permeabilization was recently challenged by the finding of a functional translocase, TOM complex, in the outer mitochondrial membrane. Evidence suggest that it is TOM, rather than $\mathrm{CL}$, that was responsible for the $\mathrm{tBid} / \mathrm{Bax}$-mediated mitochondrial permeabilization [157].

The insertion of activated Bax in the outer mitochondrial membrane by caspase- 8 produced tBid, the interaction of Bax/ TOM, the oligomerization and induction of pore formation and subsequent release of pro-apoptotic proteins into the cytosol were documented in isolated mitochondria from different Saccharomices cerevisiae yeast mutants [157], consistent with the expected sequence of events in the initiation of apoptosis. Whether TOM displays a similar quantitative role mitochondrial permeabilization in mammalian cells remains to be explored.

\section{Caspase activation and execution of apoptosis}

The main players in the execution phase of apoptosis are members of a highly conserved family of proteins, the caspases. Caspases are cysteine proteases that target substrate aspartate residues and are expressed as single chain polypeptides composed of three domains: an N-terminal pro-peptide, a large subunit and a small sub-unit. The mammalian caspase family contains at least 14 members that are categorized according to substrate specificity, domain composition or their intracellular role [158]. Initiator or apical caspases function to integrate apoptotic signals at the death receptor or at the mitochondria with signal propagation to the execution phase. Initiator caspases possess long $\mathrm{N}$-terminal prodomains that contain either a death effector domain (DED) such as in caspases 8 and -10 or a caspase activation and recruiting domain (CARD) such as in caspases 2 and -9. The homodimerization and activation of initiator caspases occur through the formation of multiprotein complexes to which caspases are recruited via their $\mathrm{N}$-terminal pro-domains. As initiator caspases of the extrinsic and intrinsic apoptosis pathways, caspase- 8 and caspase- 9 are, respectively, activated at the death inducing signalling complex (DISC) and the apoptosome complex (see Figure 1). It is notable that the dynamic integrity of the apoptosome complex which comprises Apaf-1, cyt $c$ and pro-caspase-9 is sensitive to cellular ATP concentrations wherein physiological levels of ATP binds cyt $c$ and disrupt 
apoptosome formation [159]. During apoptosis, an early decrease in cellular ATP contributed to caspase-9 activation [160]. Downstream targets of initiator caspases are effector caspases which include caspases- 3 and -7 ; in turn, activated caspase- 3 cleaves procaspases- 2 and -6 that participate in procaspase- 9 processing, thus resulting in an amplification loop [161].

The function of caspases is largely determined by modulators of the catalytic activity. Effector caspases typically exist as monomeric inactive zymogen in the cytoplasm and are activated by direct proteolysis at internal sites [162]. To date, substrates of effector caspases comprised of a broad spectrum of over 400 proteins that include mediators and regulators of apoptosis, as well as structural proteins, DNA repair proteins and cell-cycle related proteins [163]. The basal catalytic activity of caspases is suppressed by specific members of the inhibitor of apoptosis (IAP) family, such as XIAP, c-IAP1, c-IAP2 and survivin which bind at their Baculovirus IAP repeat (BIR) domains [164]. Suppression of enzyme activity during apoptosis is prevented by mitochondria-derived IAP antagonist proteins like Smac/Diablo and Omi/ HtrA2 [165,166]. Post-translational modification of caspases represents an important mode of modulation of enzyme activity. The cysteine residue in the catalytic QACRG motif of caspases is sensitive to ROS and changes in the intracellular redox environment, such as the GSH status. In Jurkat cells, treatment with different doses of $\mathrm{H}_{2} \mathrm{O}_{2}$ resulted in inhibition of caspase activation through altering the cellular GSH redox status or in suppression of caspase activity through oxidation of the catalytic site cysteine [167]. Singlet oxygen was recently reported to directly inhibit capsases- 9 and- 3 activation in HepG2 cells [168]. In this instance, endoperoxide-derived singlet oxygen induced the release of cyt $c$ into the cytosol that triggered an atypical apoptotic pathway due to caspase inactivation. A follow-up study revealed that amino acid residues of serine and cysteine proteases were specifically sensitive to oxidation induced by singlet oxygen [169].

Increasingly, the cellular GSH status is recognized to be an important player in the posttranslational modification of specific cysteine residues in a process termed S-glutathiolation, the formation of mixed disulphides between redox-sensitive cysteine and GSSG [170]. This thiol-disulphide modification of protein cysteine moieties is viewed as protective against the irreversible oxidation of cysteine [171] and reversible S-glutathiolation of caspases has gained much interest as a sensitive mechanism for caspase activation in apoptotic signalling. For instance, Pan and Berk recently demonstrated that glutathiolation regulated TNF- $\alpha$ induced caspase- 3 cleavage and endothelial cell apoptosis in that caspase 3 S-glutathiolation was inversely correlated with cytokine-induced caspase- 3 proteolytic cleavage and, thus, activation and apoptosis resistance [172]. Thiol transferase was mediated by the redox protein, glutaredoxin, which played a key role in caspase- 3 deglutathiolation and enzyme activation [173]. These findings underscore the importance of GSH/GSSG involvement in the redox-sensitive regulation of TNF- $\alpha$-induced cell apoptosis through S-glutathiolation and Grx-mediated deglutathiolation of caspase-3 [173]. Additional evidence supporting inhibition of caspase-3 activity by S-glutathiolation comes from recent studies by Huang et al. [174] in HL60 cells. The investigators found that GSSG, at physiological concentrations, can induce S-glutathiolation of caspase-3 and inhibition of enzyme activity [174]. Caspase-3 activity was fully recovered by incubation of cell extracts with DTT, confirming that cysteine residues were modified. Mass spectroscopy revealed that cysteine residues of both large and small subunits were glutathiolated [174]. Interestingly, procaspases, such as 9 and 3 , were also subject to S-glutathiolation, suggesting that GSH can regulate caspase function at the level of its catalytic activity as well as its proteolytic activation [174]. Other investigators have shown a GSH dependence of death receptor-mediated apoptosis wherein GSH sufficiency was critical in the activation of procaspase-8 $[58,60,175]$. Mechanistic studies in lymphoid cell lines demonstrated that GSH depletion suppressed Fas-induced apoptosis in association with inhibition of pro-caspase-8 activation at the Fas receptor and 
the DISC [175]. Interestingly, the formation of the DISC complex itself was unaffected by the GSH-depleted state [175], suggesting that GSH specifically targets the proteolytic cleavage and activation of pro-caspase- 8 . The precise mechanism of how GSH mediates post-translational caspase-8 activation is unresolved and could likely involve Sglutathiolation of redox sensitive cysteine residues in a manner similar to caspase-3 activation.

Besides GSH, current experimental evidence also implicates a critical role for nitric oxide $\left(\mathrm{NO}^{\circ}\right)$ in redox regulation of caspase activity and apoptotic signalling [176] which warrant some discussion. Reversible S-nitrosation of protein cysteine residues by $\mathrm{NO}^{\bullet}$ results in nitrosothiol formation; nitrosation of critical cysteine residues in the catalytic site is commonly associated with caspase inactivation and apoptosis prevention [177,178]. For instance, basal S-nitrosation of pro-caspases-9 and -3 has been shown in various cell lines in the quiescent state and apoptotic stimuli induce denitrosation and activation of catalytic activity of caspases and cell apoptosis [179-181]. An $\mathrm{NO}^{\circ}$-dependent anti-apoptotic mechanism has been described in cultured human $\mathrm{T}$ cells wherein nitrosated Trx 1 mediated the S-transnitrosation of $\mathrm{NO}^{*}$ and cysteine of pro-caspase-3, resulting in enzyme inactivation and blunted apoptotic cascade [182]. At the level of the apoptosome, $\mathrm{NO}^{\circ}$ appears to directly impede the interaction of Apaf-1 and pro-caspase-9, thus preventing the propagation of downstream caspase cascade [183].

\section{Concluding remarks}

Apoptosis is a highly orchestrated biological process in tissue turnover and organ homeostasis and has gained steady recognition as an important cell death pathway in pathobiology and various disease states. While much is known about the components of the apoptotic pathway and its inducers, there remain major unanswered questions regarding the mechanism of regulation of this complex multi-step process. Increasingly, we have witnessed a growing appreciation of the role of GSH in redox signalling beyond its traditionally recognized role as the main cellular antioxidant against oxidative challenge. The heightened interest in GSH in post-translational control of cellular processes has brought to the fore the versatility of this ubiquitious molecule that is present in millimolar concentrations in most cells and whose homeostasis is rigorously controlled by GSH redox enzymes and glutamate-cysteine ligase-driven GSH synthesis. Although synthesized exclusively in the cytosol, GSH is distributed to different cellular compartments where it maintains distinct redox environments uniquely suited to the function of the organelle, be it protein folding in the endoplasmic reticulum or gene transcription in the nucleus. Importantly, compartmentation of the GSH redox system, together with those of redox proteins like thioredoxin, is one key to the specificity of redox regulation. With regards to apoptosis, the mitochondrial GSH redox status is emerging to be a central player. Our studies have provided new perspectives on the role of mitochondrial GSH in mitochondrial DNA integrity and cell survival and the availability of genetic approaches targeting mitochondrial GSH transporters offers new strategies for studying the importance of this redox compartment in apoptosis. The current understanding of protein S-glutathiolation in conjunction with protein S-nitrosation as important post-translational regulatory mechanisms has contributed to recent advances in apoptosis research. Precisely how Sglutathiolation of specific protein sets and compartmentation of redox signalling translate to signals that decide cell fate such as apoptosis is unresolved and remains a key challenge for future research. 


\section{Abbreviations}

$\gamma-G G T$

ADP

AIF

Apaf-1

APE

ASK-1, -2

ATP

Bax

Bcl-2

BER

Bid

BIR

BSO

CARD

caspase-8,-9,-3

CJ

CL

CL-OOH

cypD

Cys

cyt $c$

DCVC

DED

DIC

DISC

DP

ER

FADD

FasL

G6PD

GAPDH

GCL

Glu

Gly

GPx $\gamma$-glutamyltransferase

adenosine diphosphate

apoptosis inducing factor

apoptotic protease activation factor-1

apurinic/apyrimidinic endonuclease

apoptosis signal-regulating kinase $1,-2$

adenosine triphosphate

pro-apoptotic protein Bax

anti-apoptotic protein

base excision repair

BH3-only pro-apoptotic protein Bid

Baculovirus IAP repeat

buthionine sulphoximine

caspase activation and recruiting domain

active form of caspase- $8,-9,-3$

cristae junction

cardiolipin

peroxidized cardiolipin

cyclophylin D

cysteine

cytochrome $c$

S-(1,2-dichlorevinyl)-L-cysteine

death effector domain

dicarboxylate carrier

death-inducing signalling complex

dipeptidase

endoplasmic reticulum

Fas-associated death domain

Fas ligand

glucose-6-phosphate dehydrogenase

glyceraldehyde-3-phospate dehydrogenase

glutamate-cysteine ligase

glutamic acid

glycine

GSH peroxidase 


\begin{tabular}{ll} 
GR & GSH reductase \\
GS & glutathione synthase \\
GSH & glutathione \\
GSSG & glutathione disulphide \\
H2O2 & hydrogen peroxide \\
HDM2 & human double minute 2 protein \\
IAA & iodoacetic acid \\
JNK & c-Jun N-terminal kinase \\
MPT & mitochondrial permeability transition \\
mtDNA & mitochondrial DNA \\
mtGSH/GSSG & mitochondrial GSH/GSSG \\
NAC & N-acetylcysteine \\
NER & nucleotide excision repair \\
NO• & nitric oxide \\
OGC & oxoglutarate carrier \\
OGG1 & 8-oxodG glycosylase \\
OPA1 & optic atrophya 1 protein \\
PTP & permeability transition pore \\
ROS & reactive oxygen species \\
RNO & reactive nitrogen species \\
Smac/Diablo & second mitochondria-derived activator of caspases/direct IAP binding \\
tBH & protein with low pI \\
TBid & tert-butyl hydroperoxide \\
TRAF2/6 & truncated form of Bid \\
Trx1 & 2,3,7,8-tetrachloredibenzo-p-dioxin \\
Trx2 & TNF $\alpha$ receptor-associated factor 2/6 \\
TRX-S-S & thioredoxin 1, reduced form \\
VDAC & \\
& thioredoxin 2, reduced form \\
\hline &
\end{tabular}

\section{Acknowledgments}

Research in the authors' laboratory was supported by a grant from the National Institutes of Health, DK44510.

\section{References}

1. Edinger AL, Thompson CB. Death by design: apoptosis, necrosis and autophagy. Curr Opin Cell Biol. 2004; 16:663-669. [PubMed: 15530778]

Free Radic Res. Author manuscript; available in PMC 2011 September 13. 
2. Okouchi M, Ekshyyan O, Maracine M, Aw TY. Neuronal apoptosis in neurodegeneration. Antioxid Redox Signal. 2007; 9:1059-1096. [PubMed: 17571960]

3. Samraj AK, Keil E, Ueffing N, Schulze-Osthoff K, Schmitz I. Loss of caspase-9 provides genetic evidence for the type I/II concept of CD95-mediated apoptosis. J Biol Chem. 2006; 281:2965229659. [PubMed: 16895904]

4. Susin SA, Lorenzo HK, Zamzami N, Marzo I, Snow BE, Brothers GM, Mangion J, Jacotot E, Costantini P, Loeffler M, Larochette N, Goodlett DR, Aebersold R, Siderovski DP, Penninger JM, Kroemer G. Molecular characterization of mitochondrial apoptosis-inducing factor. Nature. 1999; 397:441-446. [PubMed: 9989411]

5. Zamzami N, Kroemer G. The mitochondrion in apoptosis: how Pandora's box opens. Nat Rev Mol Cell Biol. 2001; 2:67-71. [PubMed: 11413468]

6. Crompton M. The mitochondrial permeability transition pore and its role in cell death. Biochem J. 1999; 341:233-249. [PubMed: 10393078]

7. Baines CP, Kaiser RA, Sheiko T, Craigen WJ, Molkentin JD. Voltage-dependent anion channels are dispensable for mi-tochondrial-dependent cell death. Nat Cell Biol. 2007; 9:550-555. [PubMed: 17417626]

8. Kokoszka JE, Waymire KG, Levy SE, Sligh JE, Cai J, Jones DP, Macgregor GR, Wallace DC. The ADP/ATP translocator is not essential for the mitochondrial permeability transition pore. Nature. 2004; 427:461-465. [PubMed: 14749836]

9. Schinzel AC, Takeuchi O, Huang Z, Fisher JK, Zhou Z, Rubens J, Hetz C, Danial NN, Moskowitz MA, Korsmeyer SJ. Cyclophilin D is a component of mitochondrial permeability transition and mediates neuronal cell death after focal cerebral ischemia. Proc Natl Acad Sci USA. 2005; 102:12005-12010. [PubMed: 16103352]

10. Tarze A, Deniaud A, Le Bras M, Maillier E, Molle D, Larochette N, Zamzami N, Jan G, Kroemer $\mathrm{G}$, Brenner C. GAPDH, a novel regulator of the pro-apoptotic mitochondrial membrane permeabilization. Oncogene. 2007; 26:2606-2620. [PubMed: 17072346]

11. Honda HM, Korge P, Weiss JN. Mitochondria and ischemia/ reperfusion injury. Ann NY Acad Sci. 2005; 1047:248-258. [PubMed: 16093501]

12. Li Y, Johnson N, Capano M, Edwards M, Crompton M. Cyclophilin-D promotes the mitochondrial permeability transition but has opposite effects on apoptosis and necrosis. Biochem J. 2004; 383:101-109. [PubMed: 15233627]

13. Eskes R, Desagher S, Antonsson B, Martinou JC. Bid induces the oligomerization and insertion of Bax into the outer mitochondrial membrane. Mol Cell Biol. 2000; 20:929-935. [PubMed: 10629050]

14. Narita M, Shimizu S, Ito T, Chittenden T, Lutz RJ, Matsuda H, Tsujimoto Y. Bax interacts with the permeability transition pore to induce permeability transition and cytochrome c release in isolated mitochondria. Proc Natl Acad Sci USA. 1998; 95:14681-14686. [PubMed: 9843949]

15. Zhang D, Lu C, Whiteman M, Chance B, Armstrong JS. The mitochondrial permeability transition regulates cytochrome $\mathrm{c}$ release for apoptosis during endoplasmic reticulum stress by remodeling the cristae junction. J Biol Chem. 2008; 283:3476-3486. [PubMed: 18056990]

16. Frezza C, Cipolat S, Martins De Brito O, Micaroni M, Beznoussenko GV, Rudka T, Bartoli D, Polishuck RS, Danial NN, De Strooper B, Scorrano L. OPA1 controls apoptotic cristae remodeling independently from mitochondrial fusion. Cell. 2006; 126:177-189. [PubMed: 16839885]

17. Dickinson DA, Forman HJ. Cellular glutathione and thiols metabolism. Biochem Pharmacol. 2002; 64:1019-1026. [PubMed: 12213601]

18. Meister A, Tate SS. Glutathione and related gammaglutamyl compounds: biosynthesis and utilization. Annu Rev Biochem. 1976; 45:559-604. [PubMed: 9027]

19. Griffith OW, Meister A. Potent and specific inhibition of glutathione synthesis by buthionine sulfoximine (S-n-butyl homocysteine sulfoximine). J Biol Chem. 1979; 254:7558-7560. [PubMed: 38242]

20. Meister A, Anderson ME, Hwang O. Intracellular cysteine and glutathione delivery systems. J Am Coll Nutr. 1986; 5:137-151. [PubMed: 3722629]

21. Meister A, Anderson ME. Glutathione. Annu Rev Biochem. 1983; 52:711-760. [PubMed: 6137189] 
22. Chinta SJ, Kumar JM, Zhang H, Forman HJ, Andersen JK. Up-regulation of gamma-glutamyl transpeptidase activity following glutathione depletion has a compensatory rather than an inhibitory effect on mitochondrial complex I activity: implications for Parkinson's disease. Free Radic Biol Med. 2006; 40:1557-1563. [PubMed: 16632116]

23. Ballatori N, Dutczak WJ. Identification and characterization of high and low affinity transport systems for reduced glutathione in liver cell canalicular membranes. J Biol Chem. 1994; 269:19731-19737. [PubMed: 8051053]

24. Anderson ME, Meister A. Transport and direct utilization of gamma-glutamylcyst(e)ine for glutathione synthesis. Proc Natl Acad Sci USA. 1983; 80:707-711. [PubMed: 6572362]

25. Hagen TM, Aw TY, Jones DP. Glutathione uptake and protection against oxidative injury in isolated kidney cells. Kidney Int. 1988; 34:74-81. [PubMed: 3172638]

26. Lash LH, Putt DA. Renal cellular transport of exogenous glutathione: heterogeneity at physiological and pharmacological concentrations. Biochem Pharmacol. 1999; 58:897-907. [PubMed: 10449202]

27. Parks LD, Zalups RK, Barfuss DW. Luminal and basolateral membrane transport of glutathione in isolated perfused $\mathrm{S}(1), \mathrm{S}(2)$, and $\mathrm{S}(3)$ segments of the rabbit proximal tubule. J Am Soc Nephrol. 2000; 11:1008-1015. [PubMed: 10820164]

28. Lash LH, Jones DP. Transport of glutathione by renal basallateral membrane vesicles. Biochem Biophys Res Commun. 1983; 112:55-60. [PubMed: 6838619]

29. Lash LH, Jones DP. Renal glutathione transport. Characteristics of the sodium-dependent system in the basal-lateral membrane. J Biol Chem. 1984; 259:14508-14514. [PubMed: 6501304]

30. Lash LH, Tokarz JJ, Chen Z, Pedrosi BM, Woods EB. ATP depletion by iodoacetate and cyanide in renal distal tubular cells. J Pharmacol Exp Ther. 1996; 276:194-205. [PubMed: 8558430]

31. Bass R, Ruddock LW, Klappa P, Freedman RB. A major fraction of endoplasmic reticulumlocated glutathione is present as mixed disulfides with protein. J Biol Chem. 2004; 279:52575262. [PubMed: 14630926]

32. Nardai G, Stadler K, Papp E, Korcsmaros T, Jakus J, Csermely P. Diabetic changes in the redox status of the microsomal protein folding machinery. Biochem Biophys Res Commun. 2005; 334:787-795. [PubMed: 16023999]

33. Dixon BM, Heath SH, Kim R, Suh JH, Hagen TM. Assessment of endoplasmic reticulum glutathione redox status is confounded by extensive ex vivo oxidation. Antioxid Redox Signal. 2008; 10:963-972. [PubMed: 18205546]

34. Hwang C, Sinskey AJ, Lodish HF. Oxidized redox state of glutathione in the endoplasmic reticulum. Science. 1992; 257:1496-1502. [PubMed: 1523409]

35. Chakravarthi S, Jessop CE, Bulleid NJ. The role of glutathione in disulphide bond formation and endoplasmic-reticulum-generated oxidative stress. EMBO Rep. 2006; 7:271-275. [PubMed: 16607396]

36. Jessop CE, Bulleid NJ. Glutathione directly reduces an oxidoreductase in the endoplasmic reticulum of mammalian cells. J Biol Chem. 2004; 279:55341-55347. [PubMed: 15507438]

37. Frand AR, Kaiser CA. Two pairs of conserved cysteines are required for the oxidative activity of Ero1p in protein disulfide bond formation in the endoplasmic reticulum. Mol Biol Cell. 2000; 11:2833-2843. [PubMed: 10982384]

38. Cotgreave IA. Analytical developments in the assay of intra-and extracellular GSH homeostasis: specific protein S-glutathionylation, cellular GSH and mixed disulphide compartmentalisation and interstitial GSH redox balance. Biofactors. 2003; 17:269-277. [PubMed: 12897448]

39. Chen J, Delannoy M, Odwin S, He P, Trush MA, Yager JD. Enhanced mitochondrial gene transcript, ATP, bcl-2 protein levels, and altered glutathione distribution in ethinyl estradioltreated cultured female rat hepatocytes. Toxicol Sci. 2003; 75:271-278. [PubMed: 12857939]

40. Holmgren A. Thioredoxin and glutaredoxin systems. J Biol Chem. 1989; 264:13963-13966. [PubMed: 2668278]

41. Holmgren A. The function of thioredoxin and glutathione in deoxyribonucleic acid synthesis. Biochem Soc Trans. 1977; 5:611-612. [PubMed: 332555] 
42. Bellomo G, Palladini G, Vairetti M. Intranuclear distribution, function and fate of glutathione and glutathione-S-conjugate in living rat hepatocytes studied by fluorescence microscopy. Microsc Res Tech. 1997; 36:243-252. [PubMed: 9140925]

43. Thomas M, Nicklee T, Hedley DW. Differential effects of depleting agents on cytoplasmic and nuclear non-protein sulphydryls: a fluorescence image cytometry study. Br J Cancer. 1995; 72:4550. [PubMed: 7599065]

44. Soderdahl T, Enoksson M, Lundberg M, Holmgren A, Ottersen OP, Orrenius S, Bolcsfoldi G, Cotgreave IA. Visualization of the compartmentalization of glutathione and protein-glutathione mixed disulfides in cultured cells. Faseb J. 2003; 17:124-126. [PubMed: 12475911]

45. Markovic J, Borras C, Ortega A, Sastre J, Vina J, Pallardo FV. Glutathione is recruited into the nucleus in early phases of cell proliferation. J Biol Chem. 2007; 282:20416-20424. [PubMed: 17452333]

46. Ho YF, Guenthner TM. Isolation of liver nuclei that retain functional trans-membrane transport. J Pharmacol Toxicol Methods. 1997; 38:163-168. [PubMed: 9523770]

47. Voehringer DW, Mcconkey DJ, Mcdonnell TJ, Brisbay S, Meyn RE. Bcl-2 expression causes redistribution of glutathione to the nucleus. Proc Natl Acad Sci USA. 1998; 95:2956-2960. [PubMed: 9501197]

48. Jocelyn PC, Kamminga A. The non-protein thiol of rat liver mitochondria. Biochim Biophys Acta. 1974; 343:356-362. [PubMed: 4838321]

49. Schnellmann RG. Renal mitochondrial glutathione transport. Life Sci. 1991; 49:393-398. [PubMed: 1857187]

50. Chen Z, Lash LH. Evidence for mitochondrial uptake of glutathione by dicarboxylate and 2oxoglutarate carriers. J Pharmacol Exp Ther. 1998; 285:608-618. [PubMed: 9580605]

51. Zimmermann AK, Loucks FA, Schroeder EK, Bouchard RJ, Tyler KL, Linseman DA. Glutathione binding to the Bcl-2 homology-3 domain groove: a molecular basis for $\mathrm{Bcl}-2$ antioxidant function at mitochondria. J Biol Chem. 2007; 282:29296-29304. [PubMed: 17690097]

52. Franco R, Cidlowski JA. SLCO/OATP-like transport of glutathione in FasL-induced apoptosis: glutathione efflux is coupled to an organic anion exchange and is necessary for the progression of the execution phase of apoptosis. J Biol Chem. 2006; 281:29542-29557. [PubMed: 16857677]

53. Hammond CL, Marchan R, Krance SM, Ballatori N. Glutathione export during apoptosis requires functional multidrug resistance-associated proteins. J Biol Chem. 2007; 282:14337-14347. [PubMed: 17374608]

54. Di Stefano A, Frosali S, Leonini A, Ettorre A, Priora R, Di Simplicio FC, Di Simplicio P. GSH depletion, protein S-glutathionylation and mitochondrial transmembrane potential hyperpolarization are early events in initiation of cell death induced by a mixture of isothiazolinones in HL60 cells. Biochim Biophys Acta. 2006; 1763:214-225. [PubMed: 16458373]

55. Han YH, Kim SH, Kim SZ, Park WH. Intracellular GSH levels rather than ROS levels are tightly related to AMA-induced HeLa cell death. Chem Biol Interact. 2008; 171:67-788. [PubMed: 17935707]

56. Merad-Boudia M, Nicole A, Santiard-Baron D, Saille C, Ceballos-Picot I. Mitochondrial impairment as an early event in the process of apoptosis induced by glutathione depletion in neuronal cells: relevance to Parkinson's disease. Biochem Pharmacol. 1998; 56:645-655. [PubMed: 9783733]

57. Lu C, Armstrong JS. Role of calcium and cyclophilin D in the regulation of mitochondrial permeabilization induced by glutathione depletion. Biochem Biophys Res Commun. 2007; 363:572-577. [PubMed: 17888874]

58. Friesen C, Kiess Y, Debatin KM. A critical role of glutathione in determining apoptosis sensitivity and resistance in leukemia cells. Cell Death Differ. 2004; 11 Suppl 1:S73-S85. [PubMed: 15105835]

59. Watson RW, Rotstein OD, Jimenez M, Parodo J, Marshall JC. Augmented intracellular glutathione inhibits Fas-triggered apoptosis of activated human neutrophils. Blood. 1997; 89:4175-4181. [PubMed: 9166861] 
60. Musallam L, Ethier C, Haddad PS, Denizeau F, Bilodeau M. Resistance to Fas-induced apoptosis in hepatocytes: role of GSH depletion by cell isolation and culture. Am J Physiol Gastrointest Liver Physiol. 2002; 283:G709-G718. [PubMed: 12181187]

61. Hentze H, Gantner F, Kolb SA, Wendel A. Depletion of hepatic glutathione prevents death receptor-dependent apoptotic and necrotic liver injury in mice. Am J Pathol. 2000; 156:20452056. [PubMed: 10854226]

62. Hentze H, Kunstle G, Volbracht C, Ertel W, Wendel A. CD95-Mediated murine hepatic apoptosis requires an intact glutathione status. Hepatology. 1999; 30:177-185. [PubMed: 10385654]

63. Pias EK, Aw TY. Early redox imbalance mediates hydroperoxide-induced apoptosis in mitotic competent undifferentiated PC-12 cells. Cell Death Differ. 2002; 9:1007-1016. [PubMed: 12181751]

64. Pias EK, Ekshyyan OY, Rhoads CA, Fuseler J, Harrison L, Aw TY. Differential effects of superoxide dismutase isoform expression on hydroperoxide-induced apoptosis in PC-12 cells. J Biol Chem. 2003; 278:13294-13301. [PubMed: 12551919]

65. Pias EK, Aw TY. Apoptosis in mitotic competent undifferentiated cells is induced by cellular redox imbalance independent of reactive oxygen species production. Faseb J. 2002; 16:781-790. [PubMed: 12039859]

66. Circu ML, Rodriguez C, Maloney R, Moyer MP, Aw TY. Contribution of mitochondrial GSH transport to matrix GSH status and colonic epithelial cell apoptosis. Free Radic Biol Med. 2008; 44:768-778. [PubMed: 18267208]

67. Noda T, Iwakiri R, Fujimoto K, Aw TY. Induction of mild intracellular redox imbalance inhibits proliferation of CaCo-2 cells. Faseb J. 2001; 15:2131-2139. [PubMed: 11641239]

68. Gotoh Y, Noda T, Iwakiri R, Fujimoto K, Rhoads CA, Aw TY. Lipid peroxide-induced redox imbalance differentially mediates $\mathrm{CaCo}-2$ cell proliferation and growth arrest. Cell Prolif. 2002; 35:221-235. [PubMed: 12153614]

69. Aw TY. Cellular redox: a modulator of intestinal epithelial cell proliferation. News Physiol Sci. 2003; 18:201-204. [PubMed: 14500800]

70. Okouchi M, Okayama N, Aw TY. Differential susceptibility of naive and differentiated PC-12 cells to methylglyoxal-induced apoptosis: influence of cellular redox. Curr Neurovasc Res. 2005; 2:13-22. [PubMed: 16181096]

71. Okouchi M, Okayama N, Aw TY. Hyperglycemia potentiates carbonyl stress-induced apoptosis in naive PC-12 cells: relationship to cellular redox and activator protease factor-1 expression. Curr Neurovasc Res. 2005; 2:375-386. [PubMed: 16375719]

72. Okouchi M, Okayama N, Alexander JS, Aw TY. NRF2-dependent glutamate-L-cysteine ligase catalytic subunit expression mediates insulin protection against hyperglycemia- induced brain endothelial cell apoptosis. Curr Neurovasc Res. 2006; 3:249-261. [PubMed: 17109620]

73. Kanwar M, Chan PS, Kern TS, Kowluru RA. Oxidative damage in the retinal mitochondria of diabetic mice: possible protection by superoxide dismutase. Invest Ophthalmol Vis Sci. 2007; 48:3805-3811. [PubMed: 17652755]

74. Ghosh S, Pulinilkunnil T, Yuen G, Kewalramani G, An D, Qi D, Abrahani A, Rodrigues B. Cardiomyocyte apoptosis induced by short-term diabetes requires mitochondrial GSH depletion. Am J Physiol Heart Circ Physiol. 2005; 289:H768-H776. [PubMed: 15805231]

75. Garcia-Ruiz C, Fernandez-Checa JC. Mitochondrial glutathione: hepatocellular survival-death switch. J Gastroenterol Hepatol. 2006; 21 Suppl 3:S3-S6. [PubMed: 16958667]

76. Meimaridou E, Lobos E, Hothersall JS. Renal oxidative vulnerability due to changes in mitochondrial-glutathione and energy homeostasis in a rat model of calcium oxalate urolithiasis. Am J Physiol Renal Physiol. 2006; 291:F731-F740. [PubMed: 16670437]

77. Lluis JM, Buricchi F, Chiarugi P, Morales A, Fernandez-Checa JC. Dual role of mitochondrial reactive oxygen species in hypoxia signaling: activation of nuclear factor- $\kappa \mathrm{B}$ via c-SRC and oxidant-dependent cell death. Cancer Res. 2007; 67:7368-7377. [PubMed: 17671207]

78. Hall AG. Review: the role of glutathione in the regulation of apoptosis. Eur J Clin Invest. 1999; 29:238-245. [PubMed: 10202381] 
79. Marchetti P, Decaudin D, Macho A, Zamzami N, Hirsch T, Susin SA, Kroemer G. Redox regulation of apoptosis: impact of thiol oxidation status on mitochondrial function. Eur J Immunol. 1997; 27:289-296. [PubMed: 9022031]

80. Zamzami N, Marzo I, Susin SA, Brenner C, Larochette N, Marchetti P, Reed J, Kofler R, Kroemer $\mathrm{G}$. The thiol crosslinking agent diamide overcomes the apoptosis-inhibitory effect of Bcl-2 by enforcing mitochondrial permeability transition. Oncogene. 1998; 16:1055-1063. [PubMed: 9519879]

81. Kokura S, Wolf RE, Yoshikawa T, Granger DN, Aw TY. Molecular mechanisms of neutrophilendothelial cell adhesion induced by redox imbalance. Circ Res. 1999; 84:516-524. [PubMed: 10082473]

82. Wang TG, Gotoh Y, Jennings MH, Rhoads CA, Aw TY. Lipid hydroperoxide-induced apoptosis in human colonic CaCo-2 cells is associated with an early loss of cellular redox balance. Faseb J. 2000; 14:1567-1576. [PubMed: 10928991]

83. Serviddio G, Bellanti F, Tamborra R, Rollo T, Capitanio N, Romano AD, Sastre J, Vendemiale G, Altomare E. UCP2 induces mitochondrial proton leak and increases susceptibility of nash liver to ischemia/reperfusion injury. Gut. 2008; 57:957-965. [PubMed: 18308829]

84. Hallberg E, Rydstrom J. Selective oxidation of mitochondrial glutathione in cultured rat adrenal cells and its relation to polycyclic aromatic hydrocarbon-induced cytotoxicity. Arch Biochem Biophys. 1989; 270:662-671. [PubMed: 2539778]

85. Lluis JM, Morales A, Blasco C, Colell A, Mari M, Garcia-Ruiz C, Fernandez-Checa JC. Critical role of mitochondrial glutathione in the survival of hepatocytes during hypoxia. J Biol Chem. 2005; 280:3224-3232. [PubMed: 15548523]

86. Olafsdottir K, Reed DJ. Retention of oxidized glutathione by isolated rat liver mitochondria during hydroperoxide treatment. Biochim Biophys Acta. 1988; 964:377-382. [PubMed: 3349102]

87. Fernandez-Checa JC, Garcia-Ruiz C, Ookhtens M, Kaplowitz N. Impaired uptake of glutathione by hepatic mitochondria from chronic ethanol-fed rats. Tracer kinetic studies in vitro and in vivo and susceptibility to oxidant stress. J Clin Invest. 1991; 87:397-405. [PubMed: 1991826]

88. Fernandez-Checa JC, Ookhtens M, Kaplowitz N. Effect of chronic ethanol feeding on rat hepatocytic glutathione. Compartmentation, efflux, and response to incubation with ethanol. J Clin Invest. 1987; 80:57-62. [PubMed: 2885343]

89. Wheeler MD, Nakagami M, Bradford BU, Uesugi T, Mason RP, Connor HD, Dikalova A, Kadiiska M, Thurman RG. Overexpression of manganese superoxide dismutase prevents alcoholinduced liver injury in the rat. J Biol Chem. 2001; 276:36664-36672. [PubMed: 11477087]

90. Zhao P, Kalhorn TF, Slattery JT. Selective mitochondrial glutathione depletion by ethanol enhances acetaminophen toxicity in rat liver. Hepatology. 2002; 36:326-335. [PubMed: 12143040]

91. Colell A, Garcia-Ruiz C, Miranda M, Ardite E, Mari M, Morales A, Corrales F, Kaplowitz N, Fernandez-Checa JC. Selective glutathione depletion of mitochondria by ethanol sensitizes hepatocytes to tumor necrosis factor. Gastroenterology. 1998; 115:1541-1551. [PubMed: 9834283]

92. Mari M, Caballero F, Colell A, Morales A, Caballeria J, Fernandez A, Enrich C, Fernandez-Checa JC, Garcia-Ruiz C. Mitochondrial free cholesterol loading sensitizes to TNF-and Fas-mediated steatohepatitis. Cell Metab. 2006; 4:185-198. [PubMed: 16950136]

93. Santos DL, Palmeira CM, Seica R, Dias J, Mesquita J, Moreno AJ, Santos MS. Diabetes and mitochondrial oxidative stress: a study using heart mitochondria from the diabetic Goto-Kakizaki rat. Mol Cell Biochem. 2003; 246:163-170. [PubMed: 12841358]

94. Santos NA, Catao CS, Martins NM, Curti C, Bianchi ML, Santos AC. Cisplatin-induced nephrotoxicity is associated with oxidative stress, redox state unbalance, impairment of energetic metabolism and apoptosis in rat kidney mitochondria. Arch Toxicol. 2007; 81:495-504. [PubMed: 17216432]

95. Santos NA, Bezerra CS, Martins NM, Curti C, Bianchi ML, Santos AC. Hydroxyl radical scavenger ameliorates cisplatin-induced nephrotoxicity by preventing oxidative stress, redox state unbalance, impairment of energetic metabolism and apoptosis in rat kidney mitochondria. Cancer Chemother Pharmacol. 2008; 61:145-155. [PubMed: 17396264] 
96. Whiteman M, Halliwell B. Thiourea and dimethylthiourea inhibit peroxynitrite-dependent damage: nonspecificity as hydroxyl radical scavengers. Free Radic Biol Med. 1997; 22:1309-1312. [PubMed: 9098107]

97. Hu S, Zhao H, Yin XJ, Ma JK. Role of mitochondria in silica-induced apoptosis of alveolar macrophages: inhibition of apoptosis by rhodamine $6 \mathrm{G}$ and $\mathrm{N}$-acetyl-L-cysteine. J Toxicol Environ Health A. 2007; 70:1403-1415. [PubMed: 17687726]

98. Raza H, John A. 4-hydroxynonenal induces mitochondrial oxidative stress, apoptosis and expression of glutathione S-transferase A4-4 and cytochrome P450 2E1 in PC12 cells. Toxicol Appl Pharmacol. 2006; 216:309-318. [PubMed: 16843508]

99. Cummings BS, Angeles R, Mccauley RB, Lash LH. Role of voltage-dependent anion channels in glutathione transport into yeast mitochondria. Biochem Biophys Res Commun. 2000; 276:940944. [PubMed: 11027572]

100. Martensson J, Lai JC, Meister A. High-affinity transport of glutathione is part of a multicomponent system essential for mitochondrial function. Proc Natl Acad Sci USA. 1990; 87:7185-7189. [PubMed: 2402500]

101. Chen Z, Putt DA, Lash LH. Enrichment and functional reconstitution of glutathione transport activity from rabbit kidney mitochondria: further evidence for the role of the dicarboxylate and 2oxoglutarate carriers in mitochondrial glutathione transport. Arch Biochem Biophys. 2000; 373:193-202. [PubMed: 10620338]

102. Lash LH, Putt DA, Matherly LH. Protection of NRK-52E cells, a rat renal proximal tubular cell line, from chemical-induced apoptosis by overexpression of a mitochondrial glutathione transporter. J Pharmacol Exp Ther. 2002; 303:476-486. [PubMed: 12388626]

103. Coll O, Colell A, Garcia-Ruiz C, Kaplowitz N, Fernandez-Checa JC. Sensitivity of the 2oxoglutarate carrier to alcohol intake contributes to mitochondrial glutathione depletion. Hepatology. 2003; 38:692-702. [PubMed: 12939596]

104. Xu F, Putt DA, Matherly LH, Lash LH. Modulation of expression of rat mitochondrial 2oxoglutarate carrier in NRK-52E cells alters mitochondrial transport and accumulation of glutathione and susceptibility to chemically induced apoptosis. J Pharmacol Exp Ther. 2006; 316:1175-1186. [PubMed: 16291728]

105. Shen D, Dalton TP, Nebert DW, Shertzer HG. Glutathione redox state regulates mitochondrial reactive oxygen production. J Biol Chem. 2005; 280:25305-25312. [PubMed: 15883162]

106. Bakkenist CJ, Kastan MB. Initiating cellular stress responses. Cell. 2004; 118:9-17. [PubMed: 15242640]

107. Yakes FM, Van Houten B. Mitochondrial DNA damage is more extensive and persists longer than nuclear DNA damage in human cells following oxidative stress. Proc Natl Acad Sci USA. 1997; 94:514-519. [PubMed: 9012815]

108. Marnett LJ. Oxyradicals and DNA damage. Carcinogenesis. 2000; 21:361-370. [PubMed: 10688856]

109. Henle ES, Linn S. Formation, prevention, and repair of DNA damage by iron/hydrogen peroxide. J Biol Chem. 1997; 272:19095-19098. [PubMed: 9235895]

110. Halliwell B, Aruoma OI. DNA damage by oxygen-derived species. Its mechanism and measurement in mammalian systems. FEBS Lett. 1991; 281:9-19. [PubMed: 1849843]

111. Salazar JJ, Van Houten B. Preferential mitochondrial DNA injury caused by glucose oxidase as a steady generator of hydrogen peroxide in human fibroblasts. Mutat Res. 1997; 385:139-149. [PubMed: 9447235]

112. Richter C, Park JW, Ames BN. Normal oxidative damage to mitochondrial and nuclear DNA is extensive. Proc Natl Acad Sci USA. 1988; 85:6465-6467. [PubMed: 3413108]

113. Klungland A, Rosewell I, Hollenbach S, Larsen E, Daly G, Epe B, Seeberg E, Lindahl T, Barnes DE. Accumulation of premutagenic DNA lesions in mice defective in removal of oxidative base damage. Proc Natl Acad Sci USA. 1999; 96:13300-13305. [PubMed: 10557315]

114. Dobson AW, Kelley MR, Wilson GL, Ledoux SP. Targeting DNA repair proteins to mitochondria. Methods Mol Biol. 2002; 197:351-362. [PubMed: 12013809] 
115. Ho R, Rachek LI, Xu Y, Kelley MR, Ledoux SP, Wilson GL. Yeast apurinic/apyrimidinic endonuclease Apn1 protects mammalian neuronal cell line from oxidative stress. J Neurochem. 2007; 102:13-24. [PubMed: 17506861]

116. Wallace DC. A mitochondrial paradigm of metabolic and degenerative diseases, aging, and cancer: a dawn for evolutionary medicine. Annu Rev Genet. 2005; 39:359-407. [PubMed: 16285865]

117. Singh KK, Russell J, Sigala B, Zhang Y, Williams J, Keshav KF. Mitochondrial DNA determines the cellular response to cancer therapeutic agents. Oncogene. 1999; 18:6641-6646. [PubMed: 10597269]

118. Ozawa T. Oxidative damage and fragmentation of mitochondrial DNA in cellular apoptosis. Biosci Rep. 1997; 17:237-250. [PubMed: 9337479]

119. Ballinger SW, Patterson C, Yan CN, Doan R, Burow DL, Young CG, Yakes FM, Van Houten B, Ballinger CA, Freeman BA, Runge MS. Hydrogen peroxide- and peroxynitrite-induced mitochondrial DNA damage and dysfunction in vascular endothelial and smooth muscle cells. Circ Res. 2000; 86:960-966. [PubMed: 10807868]

120. Ide T, Tsutsui H, Hayashidani S, Kang D, Suematsu N, Nakamura K, Utsumi H, Hamasaki N, Takeshita A. Mitochondrial DNA damage and dysfunction associated with oxidative stress in failing hearts after myocardial infarction. Circ Res. 2001; 88:529-535. [PubMed: 11249877]

121. De La Asuncion JG, Millan A, Pla R, Bruseghini L, Esteras A, Pallardo FV, Sastre J, Vina J. Mitochondrial glutathione oxidation correlates with age-associated oxidative damage to mitochondrial DNA. Faseb J. 1996; 10:333-338. [PubMed: 8641567]

122. Esteve JM, Mompo J, Garcia De La Asuncion J, Sastre J, Asensi M, Boix J, Vina JR, Vina J, Pallardo FV. Oxidative damage to mitochondrial DNA and glutathione oxidation in apoptosis: studies in vivo and in vitro. Faseb J. 1999; 13:1055-1064. [PubMed: 10336888]

123. Suliman HB, Carraway MS, Velsor LW, Day BJ, Ghio AJ, Piantadosi CA. Rapid mtDNA deletion by oxidants in rat liver mitochondria after hemin exposure. Free Radic Biol Med. 2002; 32:246-256. [PubMed: 11827750]

124. Circu, ML.; Aw, TY. Menadione-induced mitochondrial DNA damage in colonic cells: influence of cellular GSH redox status nad mitochondrial base excision repair (BER) capacity; SFRBM's 14th Annual Meeting; Washington DC. 2007. p. S148

125. Nakamura H, Nakamura K, Yodoi J. Redox regulation of cellular activation. Annu Rev Immunol. 1997; 15:351-369. [PubMed: 9143692]

126. Watson WH, Jones DP. Oxidation of nuclear thioredoxin during oxidative stress. FEBS Lett. 2003; 543:144-147. [PubMed: 12753922]

127. Hansen JM, Go YM, Jones DP. Nuclear and mitochondrial compartmentation of oxidative stress and redox signaling. Annu Rev Pharmacol Toxicol. 2006; 46:215-234. [PubMed: 16402904]

128. Hansen JM, Zhang H, Jones DP. Differential oxidation of thioredoxin-1, thioredoxin-2, and glutathione by metal ions. Free Radic Biol Med. 2006; 40:138-145. [PubMed: 16337887]

129. Kemp M, Go YM, Jones DP. Nonequilibrium thermodynamics of thiol/disulfide redox systems: a perspective on redox systems biology. Free Radic Biol Med. 2008; 44:921-937. [PubMed: 18155672]

130. Saitoh M, Nishitoh H, Fujii M, Takeda K, Tobiume K, Sawada Y, Kawabata M, Miyazono K, Ichijo H. Mammalian thioredoxin is a direct inhibitor of apoptosis signal-regulating kinase (ASK) 1. Embo J. 1998; 17:2596-2606. [PubMed: 9564042]

131. Liu Y, Min W. Thioredoxin promotes ASK1 ubiquitination and degradation to inhibit ASK1mediated apoptosis in a redox activity-independent manner. Circ Res. 2002; 90:1259-1266. [PubMed: 12089063]

132. Nishitoh H, Matsuzawa A, Tobiume K, Saegusa K, Takeda K, Inoue K, Hori S, Kakizuka A, Ichijo H. ASK1 is essential for endoplasmic reticulum stress-induced neuronal cell death triggered by expanded polyglutamine repeats. Genes Dev. 2002; 16:1345-1355. [PubMed: 12050113]

133. Fujino G, Noguchi T, Takeda K, Ichijo H. Thioredoxin and protein kinases in redox signaling. Semin Cancer Biol. 2006; 16:427-435. [PubMed: 17081769] 
134. Fujino G, Noguchi T, Matsuzawa A, Yamauchi S, Saitoh M, Takeda K, Ichijo H. Thioredoxin and TRAF family proteins regulate reactive oxygen species-dependent activation of ASK1 through reciprocal modulation of the N-terminal homophilic interaction of ASK1. Mol Cell Biol. 2007; 27:8152-8163. [PubMed: 17724081]

135. Zhang R, Al-Lamki R, Bai L, Streb JW, Miano JM, Bradley J, Min W. Thioredoxin-2 inhibits mitochondria-located ASK1-mediated apoptosis in a JNK-independent manner. Circ Res. 2004; 94:1483-1491. [PubMed: 15117824]

136. Wang XS, Diener K, Tan TH, Yao Z. MAPKKK6, a novel mitogen-activated protein kinase kinase kinase, that associates with MAPKKK5. Biochem Biophys Res Commun. 1998; 253:3337. [PubMed: 9875215]

137. Ortner E, Moelling K. Heteromeric complex formation of ASK2 and ASK1 regulates stressinduced signaling. Biochem Biophys Res Commun. 2007; 362:454-459. [PubMed: 17714688]

138. Adams JM, Cory S. The Bcl-2 protein family: arbiters of cell survival. Science. 1998; 281:13221326. [PubMed: 9735050]

139. Schlame M, Rua D, Greenberg ML. The biosynthesis and functional role of cardiolipin. Prog Lipid Res. 2000; 39:257-288. [PubMed: 10799718]

140. Van Klompenburg W, Nilsson I, Von Heijne G, De Kruijff B. Anionic phospholipids are determinants of membrane protein topology. Embo J. 1997; 16:4261-4266. [PubMed: 9250669]

141. Grijalba MT, Vercesi AE, Schreier S. Ca2+-induced increased lipid packing and domain formation in submitochondrial particles. A possible early step in the mechanism of $\mathrm{Ca} 2+-$ stimulated generation of reactive oxygen species by the respiratory chain. Biochemistry. 1999; 38:13279-13287. [PubMed: 10529202]

142. Hoch FL. Cardiolipins and biomembrane function. Biochim Biophys Acta. 1992; 1113:71-133. [PubMed: 1550861]

143. Tuominen EK, Wallace CJ, Kinnunen PK. Phospholipidcytochrome c interaction: evidence for the extended lipid anchorage. J Biol Chem. 2002; 277:8822-8826. [PubMed: 11781329]

144. Ott M, Robertson JD, Gogvadze V, Zhivotovsky B, Orrenius S. Cytochrome c release from mitochondria proceeds by a two-step process. Proc Natl Acad Sci USA. 2002; 99:1259-1263. [PubMed: 11818574]

145. Iverson SL, Orrenius S. The cardiolipin-cytochrome c interaction and the mitochondrial regulation of apoptosis. Arch Biochem Biophys. 2004; 423:37-46. [PubMed: 14989263]

146. Kagan VE, Borisenko GG, Tyurina YY, Tyurin VA, Jiang J, Potapovich AI, Kini V, Amoscato AA, Fujii Y. Oxidative lipidomics of apoptosis: redox catalytic interactions of cytochrome $\mathrm{c}$ with cardiolipin and phosphatidylserine. Free Radic Biol Med. 2004; 37:1963-1985. [PubMed: 15544916]

147. Dejean LM, Martinez-Caballero S, Kinnally KW. Is MAC the knife that cuts cytochrome c from mitochondria during apoptosis? Cell Death Differ. 2006; 13:1387-1395. [PubMed: 16676005]

148. Hardy S, El-Assaad W, Przybytkowski E, Joly E, Prentki M, Langelier Y. Saturated fatty acidinduced apoptosis in MDA-MB-231 breast cancer cells. A role for cardiolipin. J Biol Chem. 2003; 278:31861-31870. [PubMed: 12805375]

149. Kagan VE, Tyurin VA, Jiang J, Tyurina YY, Ritov VB, Amoscato AA, Osipov AN, Belikova NA, Kapralov AA, Kini V, Vlasova I, Zhao Q, Zou M, Di P, Svistunenko DA, Kurnikov IV, Borisenko GG. Cytochrome $\mathrm{c}$ acts as a cardiolipin oxygenase required for release of proapoptotic factors. Nat Chem Biol. 2005; 1:223-232. [PubMed: 16408039]

150. Shidoji Y, Hayashi K, Komura S, Ohishi N, Yagi K. Loss of molecular interaction between cytochrome $\mathrm{c}$ and cardiolipin due to lipid peroxidation. Biochem Biophys Res Commun. 1999; 264:343-347. [PubMed: 10529366]

151. Vlasova I, Tyurin VA, Kapralov AA, Kurnikov IV, Osipov AN, Potapovich MV, Stoyanovsky DA, Kagan VE. Nitric oxide inhibits peroxidase activity of cytochrome c.cardiolipin complex and blocks cardiolipin oxidation. J Biol Chem. 2006; 281:14554-14562. [PubMed: 16543234]

152. Ran Q, Liang H, Gu M, Qi W, Walter CA, Roberts LJ 2nd, Herman B, Richardson A, Van Remmen $\mathrm{H}$. Transgenic mice overexpressing glutathione peroxidase 4 are protected against oxidative stress-induced apoptosis. J Biol Chem. 2004; 279:55137-55146. [PubMed: 15496407] 
153. Kapralov AA, Kurnikov IV, Vlasova II, Belikova NA, Tyurin VA, Basova LV, Zhao Q, Tyurina YY, Jiang J, Bayir H, Vladimirov YA, Kagan VE. The hierarchy of structural transitions induced in cytochrome $\mathrm{c}$ by anionic phospholipids determines its peroxidase activation and selective peroxidation during apoptosis in cells. Biochemistry. 2007; 46:14232-14244. [PubMed: 18004876]

154. Gonzalvez F, Gottlieb E. Cardiolipin: setting the beat of apoptosis. Apoptosis. 2007; 12:877-885. [PubMed: 17294083]

155. Sorice M, Circella A, Cristea IM, Garofalo T, Di Renzo L, Alessandri C, Valesini G, Esposti MD. Cardiolipin and its metabolites move from mitochondria to other cellular membranes during death receptor-mediated apoptosis. Cell Death Differ. 2004; 11:1133-1145. [PubMed: 15181455]

156. Newmeyer DD, Ferguson-Miller S. Mitochondria: releasing power for life and unleashing the machineries of death. Cell. 2003; 112:481-490. [PubMed: 12600312]

157. Ott M, Norberg E, Walter KM, Schreiner P, Kemper C, Rapaport D, Zhivotovsky B, Orrenius S. The mitochondrial TOM complex is required for $\mathrm{tBid} / \mathrm{Bax}$-induced cytochrome $\mathrm{c}$ release. $\mathrm{J}$ Biol Chem. 2007; 282:27633-27639. [PubMed: 17635912]

158. Nicholson DW. Caspase structure, proteolytic substrates, and function during apoptotic cell death. Cell Death Differ. 1999; 6:1028-1042. [PubMed: 10578171]

159. Samali A, O’Mahoney M, Reeve J, Logue S, Szegezdi E, McMahon J, Fearnhead HO. Identification of an inhibitor of caspase activation from heart extracts; ATP blocks apoptosome formation. Apoptosis. 2007; 12:465-474. [PubMed: 17245645]

160. Chandra D, Bratton SB, Person MD, Tian Y, Martin AG, Ayres M, Fearnhead HO, Gandhi V, Tang DG. Intracellular nucleotides act as critical prosurvival factors by binding to cytochrome C and inhibiting apoptosome. Cell. 2006; 125:1333-1346. [PubMed: 16814719]

161. Slee EA, Harte MT, Kluck RM, Wolf BB, Casiano CA, Newmeyer DD, Wang HG, Reed JC, Nicholson DW, Alnemri ES, Green DR, Martin SJ. Ordering the cytochrome c-initiated caspase cascade: hierarchical activation of caspases-2, -3, -6, -7, -8, and -10 in a caspase-9-dependent manner. J Cell Biol. 1999; 144:281-292. [PubMed: 9922454]

162. Salvesen GS, Abrams JM. Caspase activation—stepping on the gas or releasing the brakes? Lessons from humans and flies. Oncogene. 2004; 23:2774-2784. [PubMed: 15077141]

163. Degterev A, Boyce M, Yuan J. A decade of caspases. Oncogene. 2003; 22:8543-8567. [PubMed: 14634618]

164. Verhagen AM, Coulson EJ, Vaux DL. Inhibitor of apoptosis proteins and their relatives: IAPs and other BIRPs. Genome Biol. 2001; 2:REVIEWS3009. [PubMed: 11516343]

165. Du C, Fang M, Li Y, Li L, Wang X. Smac, a mitochondrial protein that promotes cytochrome cdependent caspase activation by eliminating IAP inhibition. Cell. 2000; 102:33-42. [PubMed: 10929711]

166. Suzuki Y, Takahashi-Niki K, Akagi T, Hashikawa T, Takahashi R. Mitochondrial protease Omi/ HtrA2 enhances caspase activation through multiple pathways. Cell Death Differ. 2004; 11:208216. [PubMed: 14605674]

167. Hampton MB, Orrenius S. Dual regulation of caspase activity by hydrogen peroxide: implications for apoptosis. FEBS Lett. 1997; 414:552-556. [PubMed: 9323034]

168. Otsu K, Sato K, Ikeda Y, Imai H, Nakagawa Y, Ohba Y, Fujii J. An abortive apoptotic pathway induced by singlet oxygen is due to the suppression of caspase activation. Biochem J. 2005; 389:197-206. [PubMed: 15796713]

169. Suto D, Iuchi Y, Ikeda Y, Sato K, Ohba Y, Fujii J. Inactivation of cysteine and serine proteases by singlet oxygen. Arch Biochem Biophys. 2007; 461:151-158. [PubMed: 17459324]

170. Ghezzi P. Regulation of protein function by glutathionylation. Free Radic Res. 2005; 39:573-580. [PubMed: 16036334]

171. Dalle-Donne I, Rossi R, Giustarini D, Colombo R, Milzani A. S-glutathionylation in protein redox regulation. Free Radic Biol Med. 2007; 43:883-898. [PubMed: 17697933]

172. Pan S, Berk BC. Glutathiolation regulates tumor necrosis factor-alpha-induced caspase-3 cleavage and apoptosis: key role for glutaredoxin in the death pathway. Circ Res. 2007; 100:213219. [PubMed: 17185628] 
173. Sykes MC, Mowbray AL, Jo H. Reversible glutathiolation of caspase-3 by glutaredoxin as a novel redox signaling mechanism in tumor necrosis factor-alpha-induced cell death. Circ Res. 2007; 100:152-154. [PubMed: 17272816]

174. Huang Z, Pinto JT, Deng H, Richie JP Jr. Inhibition of caspase-3 activity and activation by protein glutathionylation. Biochem Pharmacol. 2008; 75:2234-2244. [PubMed: 18395187]

175. Hentze H, Schmitz I, Latta M, Krueger A, Krammer PH, Wendel A. Glutathione dependence of caspase-8 activation at the death-inducing signaling complex. J Biol Chem. 2002; 277:55885595. [PubMed: 11734564]

176. Hess DT, Matsumoto A, Kim SO, Marshall HE, Stamler JS. Protein S-nitrosylation: purview and parameters. Nat Rev Mol Cell Biol. 2005; 6:150-166. [PubMed: 15688001]

177. Kim YM, Talanian RV, Billiar TR. Nitric oxide inhibits apoptosis by preventing increases in caspase-3-like activity via two distinct mechanisms. J Biol Chem. 1997; 272:31138-31148. [PubMed: 9388267]

178. Li J, Billiar TR, Talanian RV, Kim YM. Nitric oxide reversibly inhibits seven members of the caspase family via S-nitrosylation. Biochem Biophys Res Commun. 1997; 240:419-424. [PubMed: 9388494]

179. Mannick JB, Schonhoff C, Papeta N, Ghafourifar P, Szibor M, Fang K, Gaston B. S-Nitrosylation of mitochondrial caspases. J Cell Biol. 2001; 154:1111-1116. [PubMed: 11551979]

180. Foster MW, Mcmahon TJ, Stamler JS. S-nitrosylation in health and disease. Trends Mol Med. 2003; 9:160-168. [PubMed: 12727142]

181. Kim JE, Tannenbaum SR. S-Nitrosation regulates the activation of endogenous procaspase-9 in HT-29 human colon carcinoma cells. J Biol Chem. 2004; 279:9758-9764. [PubMed: 14701803]

182. Mitchell DA, Morton SU, Fernhoff NB, Marletta MA. Thioredoxin is required for S-nitrosation of procaspase-3 and the inhibition of apoptosis in Jurkat cells. Proc Natl Acad Sci USA. 2007; 104:11609-11614. [PubMed: 17606900]

183. Zech B, Kohl R, Von Knethen A, Brune B. Nitric oxide donors inhibit formation of the Apaf-1/ caspase-9 apoptosome and activation of caspases. Biochem J. 2003; 371:1055-1064. [PubMed: 12605597] 


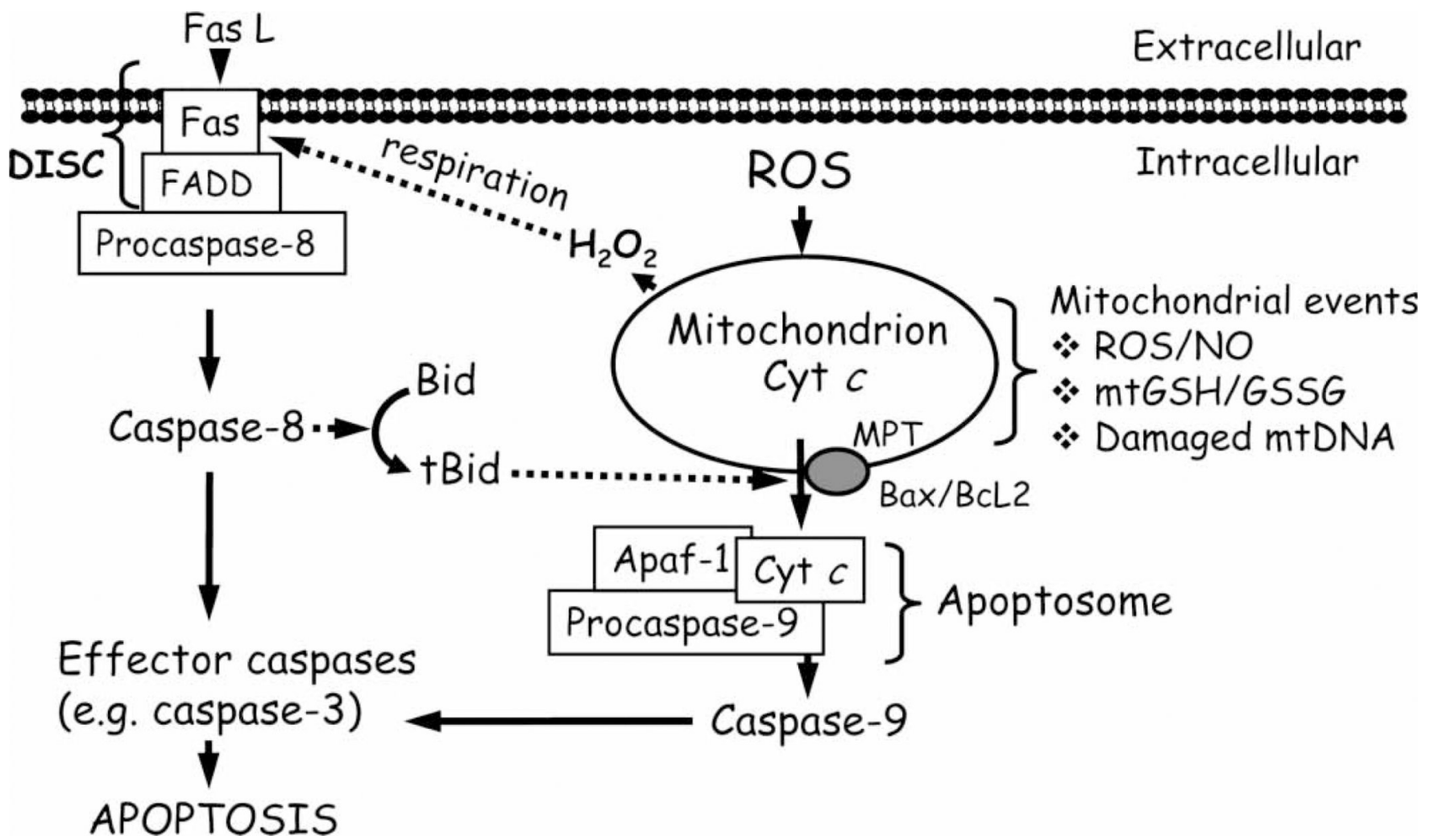

Figure 1.

Death receptor and mitochondria-mediated pathways of cellular apoptosis. Death receptor signalling is mediated by the binding of ligand, such as FasL to its membrane receptor and, together with the Fas-associated death domain (FADD), forms the death-inducing signalling complex (DISC). Subsequent activation of the initiator caspase-8 results in (A) direct activation of effector caspases, such as caspase-3 or (B) engagement of mitochondrial apoptotic signalling through cleavage of the pro-apoptotic protein, Bid. At the level of the mitochondrion, ROS/RNS; mtGSH/GSSG imbalance or an increase in mtDNA damage can stimulate apoptotic signalling which includes permeabilization of the mitochondrial membrane either via MPT opening or via pores formed by Bax and Bcl2 that results in mitochondria-to-cytosol release of apoptogenic factors such as cytochrome $c$ (cyt $c$ ). Once in the cytosol, cyt $c$, together with pro-caspase- 9 and Apaf- 1 forms the apoptosome complex. Activated caspase-9 subsequently cleaves and activates downstream effector caspase-3 or -7, which mediates the final steps of apoptosis. FasL, Fas ligand; FADD, Fas-associated death domain; DISC, death-inducing signalling complex; Bid, BH3-only pro-apoptotic protein Bid; tBid, truncated form of Bid; Bax/Bcl2, pro- and anti-apoptotic proteins, respectively; cyt $c$, cytochrome $c$; Apaf-1, apoptotic protease activation factor-1; MPT, mitochondrial permeability transition; ROS, reactive oxygen species; NO, nitric oxide; $\mathrm{mtGSH} / \mathrm{GSSG}$, mitochondrial glutathione/glutathione disulphide; mtDNA, mitochondrial DNA. 


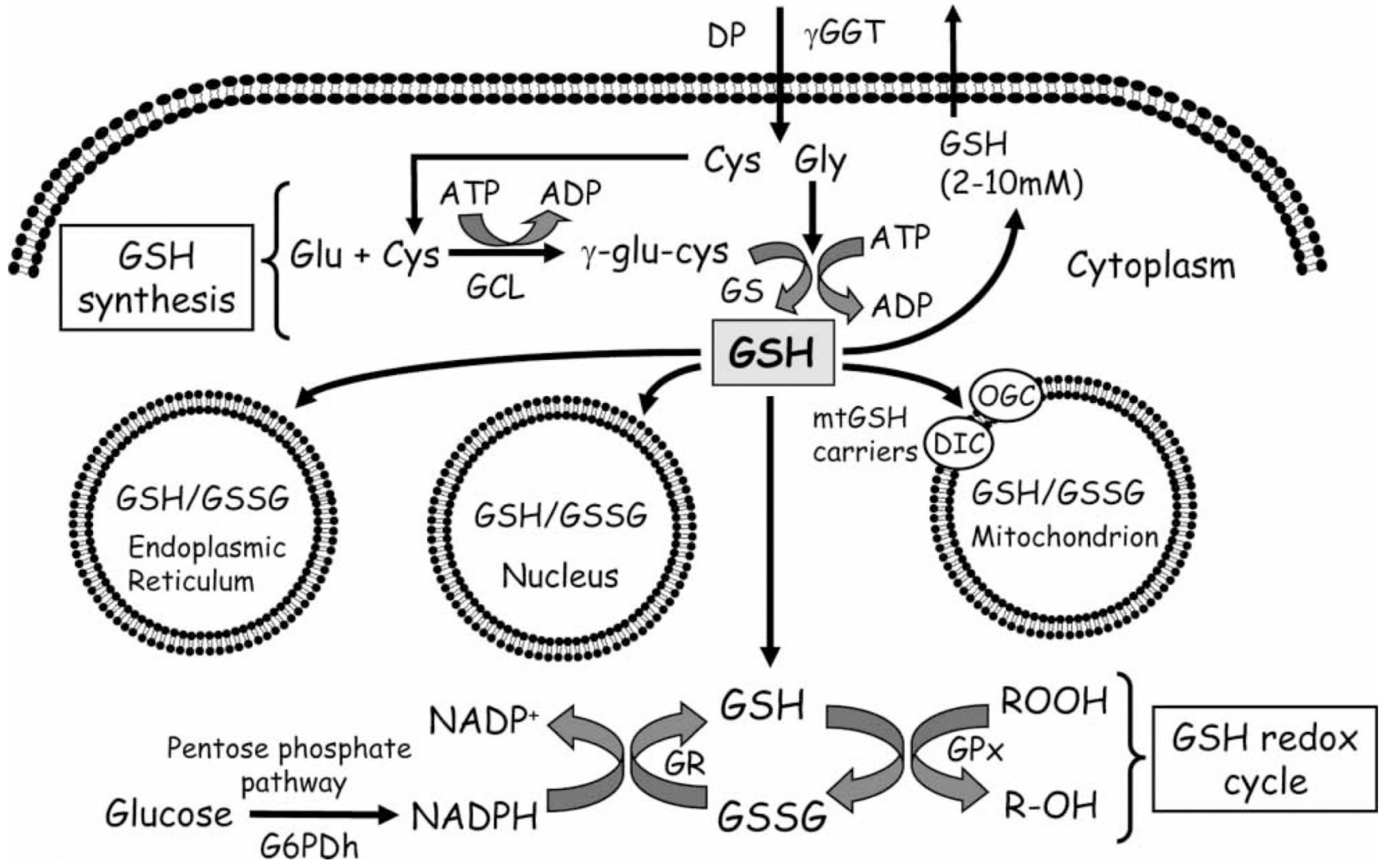

Figure 2.

Cellular GSH homeostasis: synthesis, redox cycling and compartmentation. GSH synthesis from glutamate, cysteine and glycine occurs within the cytosol via two ATP-dependent steps that are catalysed by glutamate-cysteine ligase and glutathione synthase. Extracellular GSH hydrolysis is catalysed by $\gamma$-glutamyltransferase and dipeptidase and amino acid precursors (i.e. cysteine, glycine) are transported via membrane carriers for intracellular GSH synthesis. In the GSH redox cycle, the reduction of GSSG, generated from glutathione peroxidasecatalysed detoxication of hydroperoxides, is catalysed by the flavoprotein, glutathione reductase. Pentose phosphate shunt-derived NADPH serves as the electron donor for GSSG reduction. Distinct GSH pools are compartmentalized within the mitochondria, nucleus and endoplasmic reticulum, each exhibiting unique redox environments. Dicarboxylate and oxoglutarate carriers mediate mitochondrial GSH uptake. GSH: glutathione; GSSG; glutathione disulphide; cys: cysteine; gly: glycine; glu: glutamic acid; GCL: glutamate-cysteine ligase; GS: glutathione synthase; ATP: adenosine triphosphate; ADP: adenosine diphosphate; $\gamma$ GGT: $\gamma$-glutamyl-transferase; DP: dipeptidase; GPx: GSH peroxidase; GR: GSSG reductase; G6PDh: glucose-6-phosphate dehydrogenase; DIC, OGC, dicarboxylate and oxo-glutarate carriers, respectively. 


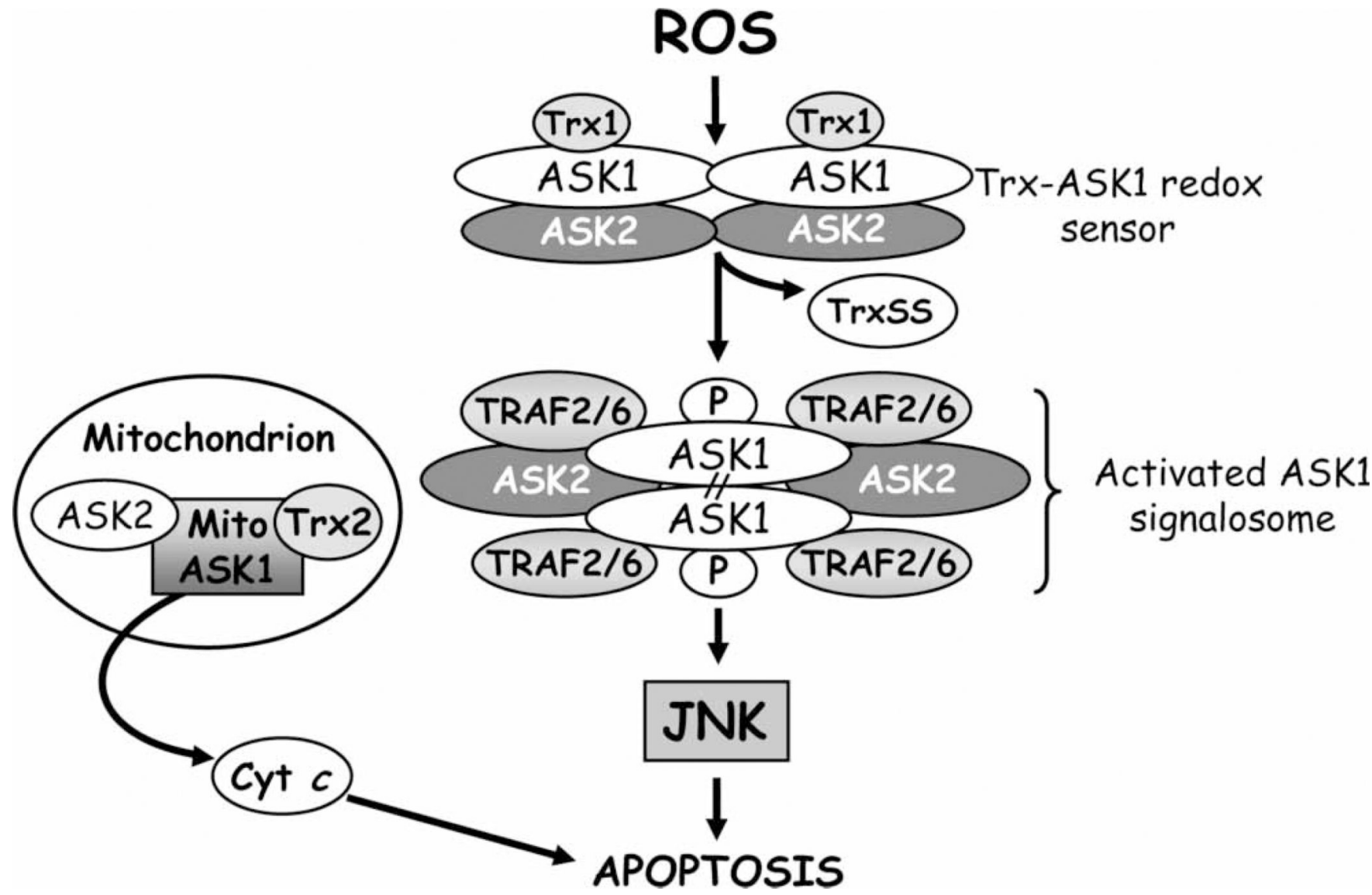

Figure 3.

Redox-mediated ASK1 signalling and apoptosis. A complex of thioredoxin and apoptosis signalling-regulating kinase 1 (Trx-ASK1), termed 'ASK1 signalsome' functions as a redox sensor in ROS-dependent activation of c-Jun N-terminal kinase and cell apoptosis. Proteins such as tumour necrosis factor receptor-associated factor 2 and 6 (TRAF 2/6) and ASK2 are recruited to the signalosome complex. ASK2 is a MAP3 kinase that is closely related to ASK1 which can form heteromeric complexes with ASK1 in the cytosol or mitochondria. Reactive oxygen species (ROS) induces thiol oxidation in the redox active site of Trx and causes TrxSS dissociation from ASK1. The release of ASK1 from Trx-ASK1 complex induces its auto-phosphorylation and formation of 'activated signalosome' through covalent binding between its sub-units which results in JNK activation. Disruption of the mitochondrial ASK1/ASK2/Trx2 complex by ROS promotes cyt $c$ release. ROS, reactive oxygen species; JNK, c-Jun N-terminal kinase, Trx1, thioredoxin 1, reduced form; Trx SS, thioredoxin, oxidized form; Trx2, thioredoxin 2; ASK1, -2, apoptosis signal-regulating kinase 1,-2; Bax, pro-apoptotic protein; Bid, BH3-only pro-apoptotic protein; cyt $c$, cytochrome $c$; TRAF2/6: TNF $\alpha$ receptor-associated factor 2,6 . 


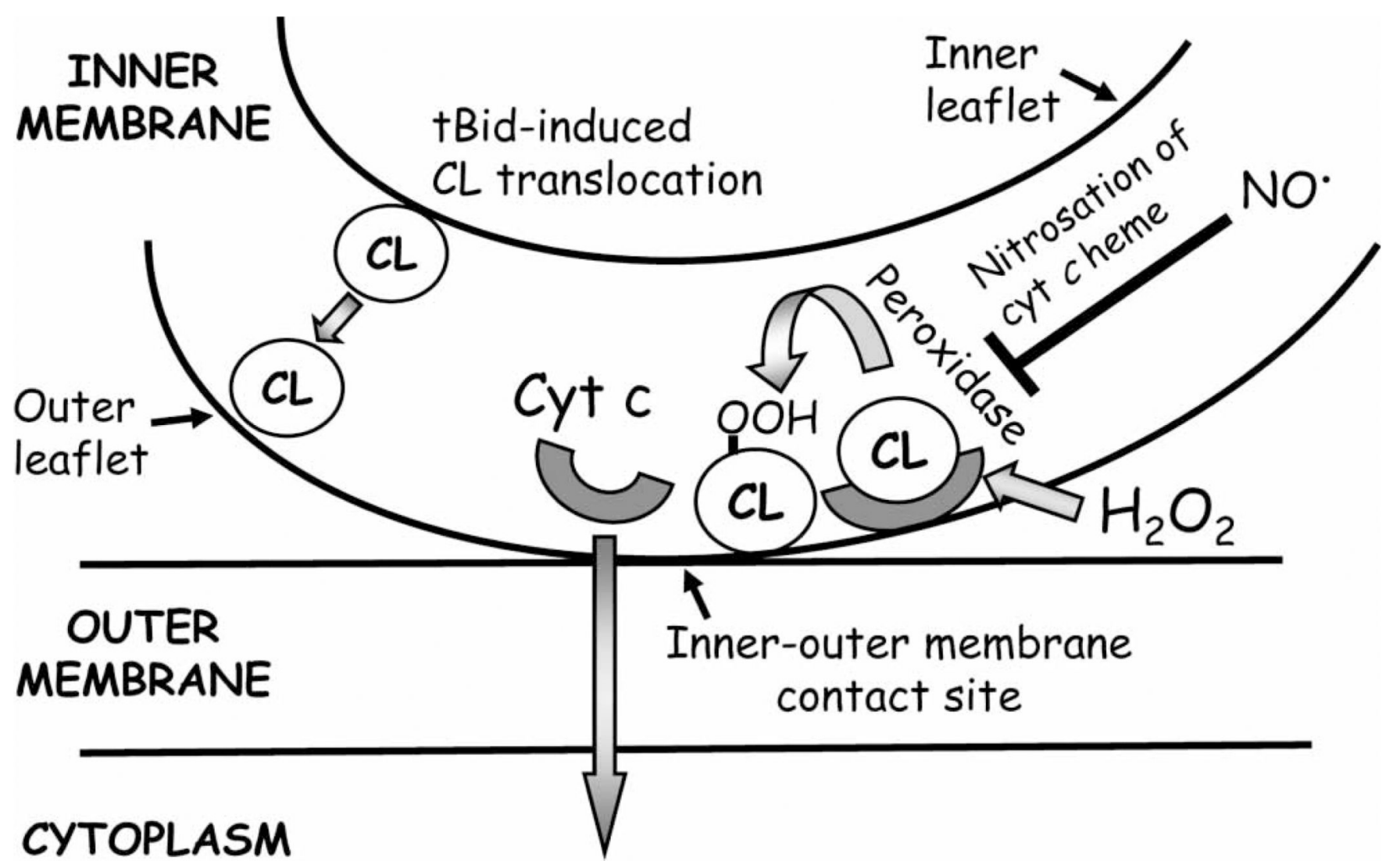

Figure 4.

Hydrogen peroxide-mediated disruption of cardiolipin-cytochrome $c$ interaction in mitochondria-to-cytosol release of cytochrome $c$. Cytochrome $c$ (cyt $c$ ) is sequestrated in the mitochondrial inter-membrane space via the interaction with the mitochondrial-specific phospholipid, cardiolipin. Elevated levels of mitochondria-derived $\mathrm{H}_{2} \mathrm{O}_{2}$ activate cyt $c$ peroxidase activity which induces peroxidation of acyl chains of cardiolipin, followed by cyt $c$ detachment from the cardiolipin-cyt $c$ complex and release from the mitochondria. Cyt $c$ peroxidase activity is inhibited by mitochondrial nitric oxide. CL, cardiolipin; CL-OOH, peroxidized cardiolipin; cyt $c$, cytochrome $\mathrm{c} ; \mathrm{H}_{2} \mathrm{O}_{2}$, hydrogen peroxide; $\mathrm{NO}^{*}$, nitric oxide. 